\title{
Phylogenetic Diversity and Effect of Temperature on Pathogenicity of Colletotrichum lupini
}

\author{
Guillaume Dubrulle, ${ }^{1}$ Flora Pensec, ${ }^{1}$ Adeline Picot, ${ }^{1}$ Karim Rigalma, ${ }^{1}$ Audrey Pawtowski, ${ }^{1}$ Sophie Nicolleau, ${ }^{2}$ Nathalie Harzic, ${ }^{3}$ \\ Patrice Nodet, ${ }^{1}$ Riccardo Baroncelli, ${ }^{1,4}$ and Gaétan Le Floch ${ }^{1, \dagger}$ \\ ${ }^{1}$ Univ. Brest, Laboratoire Universitaire de Biodiversité et Écologie Microbienne, ESIAB, F-29280 Plouzané, France \\ ${ }^{2}$ Terrena Innovation, La Noelle, 44150 Ancenis, France \\ ${ }^{3}$ Jouffray-Drillaud Semences, Station de Recherche La Litière, 86600 Saint Sauvant, France \\ ${ }^{4}$ Instituto Hispano-Luso de Investigaciones Agrarias, University of Salamanca, 37185 Villamayor (Salamanca), Spain
}

\begin{abstract}
Although lupin anthracnose caused by Colletotrichum lupini is a significant threat for spring and winter lupin crops, it has been poorly studied so far. This study aimed at characterizing the (i) phylogenetic, (ii) morphological, and (iii) physiological diversity of collected isolates from anthracnose-affected lupins. The genetic identification of representative isolates $(n=71)$ revealed that they were all $C$. lupini species, further confirming that lupin anthracnose is caused by this species. However, multilocus sequencing on these isolates and 16 additional reference strains of C. lupini revealed a separation into two distinct genetic groups, both of them characterized by a very low genetic diversity. The diversity of morphological characteristics of a selected subset of $C$. lupini isolates was further evaluated. To the best of our knowledge, microsclerotia produc-

of some strains to grow in vitro at $5^{\circ} \mathrm{C}$. This ability was also evidenced in planta, because $C$. lupini DNA was detectable in plants from 14 days postinoculation at $5^{\circ} \mathrm{C}$ onward, whereas symptoms began to appear a week later, although at a very low level. Since lupin crops are planted during winter or early spring, growth studies in vitro and in planta demonstrated the capability of the species to grow at temperatures ranging from 5 to $30^{\circ} \mathrm{C}$, with an optimum close to $25^{\circ} \mathrm{C}$. In this study, C. lupini-specific primers were also designed for real-time quantitative PCR on fungal DNA and allowed the detection of $C$. lupini in asymptomatic field samples. These results open perspectives to detect earlier and limit the development of this pathogen in lupin crops.
\end{abstract} tion observed for some isolates has never been reported so far within the Colletotrichum acutatum species complex. Finally, the modeling of growth responses of a subset of $C$. lupini strains revealed the capacity
Keywords: aggressiveness, Colletotrichum acutatum species complex, DNA quantification, Lupin anthracnose, microsclerotia
The genus Lupinus belongs to the Fabaceae family and includes annual and perennial species originating from Europe, Africa, and South America (Cowling et al. 1998). Lupins have a broad range of interesting agronomic characteristics, including self-sufficiency to nitrogen supply owing to its leguminous properties and a deep root system able to mobilize nutrients from low soil horizons. In addition, lupin seeds have a high protein content (up to 35\%) (Lee et al. 2016). Several lupin species originating from Europe are cultivated for food and feed production, including white lupin (Lupinus albus), yellow lupin (L. luteus), and narrow-leafed or blue lupin (L. angustifolius). In France, white lupin breeding has led to the adoption of vernalizing types, which may be sown early in the autumn. These cultivars resist freezing damage over winter and are less subjected to abiotic stress owing to an early flowering period (N. Harzic, personal communication).

Although the interest in lupin crops has increased over the past few years, one of the major limiting factors for lupin production remains its susceptibility to diseases, the most destructive of which is anthracnose mainly caused by Colletotrichum lupini (Damm et al. 2012; Lotter and Berger 2005; Talhinhas et al. 2016). This species belongs to the Colletotrichum acutatum species complex (CAsc) (Jayawardena et al. 2016) that mainly includes plant pathogens causing anthracnose.

${ }^{\dagger}$ Corresponding author: G. Le Floch; gaetan.lefloch@univ-brest.fr

Funding: This work was supported by "The Prograilive" project grant RBRE160116CR0530019 funded by the regions of Bretagne and Pays de la Loire and FEADER grants coordinated by G. Le Floch.

The author(s) declare no conflict of interest.

Accepted for publication 3 September 2019.

(C) 2020 The American Phytopathological Society
The first report of white lupin anthracnose established in 1912 described the causal agent as Gloeosporium lupinus in the São Paulo region of Brazil (Bondar 1912). In the 20th century, several studies isolated causal agents of lupin anthracnose and described them as Glomerella lupinicola (Seymour 1929) or C. gloeosporioides and its teleomorph Glomerella cingulata (Weimer 1943, 1951, 1952; Wells and Bell 1969; Wells and Forbes 1967). It was further demonstrated that inoculation with the sexual form of $C$. gloeosporioides induced disease symptoms on various lupin species (TeBeest 1988; Weidemann et al. 1988). The agent of lupin anthracnose was subsequently identified as $C$. gloeosporioides or C. acutatum before being taxonomically identified as $C$. lupini since 2002 based on the sequencing of six loci (Damm et al. 2012; Nirenberg et al. 2002). Although most species within the CAsc are polyphagous, a growing body of evidence suggests that $C$. lupini is a host-specific pathogen (Baroncelli et al. 2015a, b; Nirenberg et al. 2002; Sreenivasaprasad and Talhinhas 2005). However, it is not clear whether isolates from additional species are also able to cause lupin anthracnose and if so, to which degree.

Beyond the correct identifications of the pathogens causing lupin anthracnose, the magnitude of intraspecific diversity is also essential to the selection of appropriate disease control strategies. According to Guerber et al. (2003), the C. acutatum sensu lato species was divided into at least eight distinct molecular groups using RFLP methods based on glutamine synthase and sequences of the glyceraldehyde-3-phosphate dehydrogenase (GAPDH) gene. The affiliation to these groups was closely associated with phenotypic diversity, host association, and geographical distribution. Among these groups, isolates from lupin were found to belong to haplotype J2 with two isolates from France and Canada and haplotype J6 with four isolates from New Zealand and the United Kingdom (Guerber et al. 2003). Using AFLPs, PCR, and multilocus sequencing based on internal transcribed spacer (ITS), $\beta$-tubulin 2 (TUB2), and histone 4 (HIS4), Talhinhas et al. (2002) showed that Colletotrichum 
isolates from lupin were close to $C$. acutatum and that they were divided into two subgroups A1 and A2. Eight distinct molecular groups were further characterized in C. acutatum s.l. species by Sreenivasaprasad and Talhinhas (2005) based on ITS region (ITS 1, 5.8S, ITS2) and TUB2 gene sequences, with $C$. lupini belonging to the A1 group, which solely contained isolates causing lupin anthracnose. Phylogenetic analyses of $C$. lupini among the CAsc were refined using previous classifications and data on six loci, and they again demonstrated that $C$. lupini isolates were clustered into one clade (namely, clade 1) among five within CAsc (Damm et al. 2012).

Colletotrichum species are distributed worldwide (Dean et al. 2012). Early disease symptoms on lupin begin with twisting of stems, pods, and petioles; these are later accompanied with necrotic spots on which orange conidial masses can appear (i.e., acervuli) (Sweetingham et al. 1998b). In infected pods, seeds become brown and wrinkled. If able to germinate, the plantlet can exhibit necrosis in cotyledons or the hypocotyl (Gondran and Pacault 1997).

Infected lupin seeds are generally considered the primary inoculum for lupin anthracnose (Decker 1947). Previously, studies demonstrated that $0.1 \%$ of seeds infected by anthracnose induced over $50 \%$ of yield loss (Gondran et al. 1990). Infected seedlings are also able to contaminate healthy neighboring seedlings (Diggle et al. 2002). At flowering, spores can infect flowers and pods, ultimately resulting in seed contamination (White et al. 2008). Inoculum dispersal is also possible by splashing of ascospores from residues and stubble (White et al. 2008). High humidity and temperatures $>10^{\circ} \mathrm{C}$ have been shown to be conducive to conidial germination and disease onset (Sweetingham et al. 1998a), although the influence of lower temperatures has yet to be studied. It is not known whether the fungus is able to grow endophytically at low temperatures during winter, resulting in a latency phase before expressing symptoms when the conditions are favorable. Such knowledge may help devise appropriate control strategies notably through an early diagnosis in crop.

In this context, the objectives of our study were to determine (i) taxonomic diversity among $71 \mathrm{C}$. lupini isolated strains from lupin with anthracnose symptoms using a multilocus sequencing method of eight loci, (ii) the morphological and physiological diversity by studying the effect of temperatures on fungal growth among a subset of six representative strains, and (iii) their aggressiveness under optimal and suboptimal temperature conditions. Furthermore, in order to detect $C$. lupini and determine its growth in plant samples inoculated in the laboratory and collected from the field, speciesspecific primers were designed for quantitative PCR (qPCR) analyses.

\section{Materials and Methods}

Strains. The strains studied came from the CBS collection (23 strains), the IMI collection (14 strains), or reference isolates (8 strains), or they were isolated from diseased lupin plants collected in western France between 2014 and 2017 (71 strains) (Table 1).

Fungal isolation from symptomatic plants. Diseased plants were associated with metadata describing the locality, collector, date, symptomatic tissue, lupin variety, preceding crop, and phytosanitary product usage.

Diseased plant specimens were cut in 5- to 10-mm fragments and surface sterilized for $1 \mathrm{~min}$ in a solution of $1 \%$ sodium hypochlorite before being rinsed twice for $2 \mathrm{~min}$ in sterile distilled water. After drying using sterile blotting papers, plant fragments were placed on potato dextrose agar (PDA; Becton Dickinson) media with antibiotics (streptomycin $0.05 \mathrm{~g} /$ liter, penicillin $0.05 \mathrm{~g} /$ liter, and chlortetracyclin $0.05 \mathrm{~g} / \mathrm{liter}$; Sigma Aldrich). After 5 to 7 days at $25^{\circ} \mathrm{C}$, suspected Colletotrichum spp. were identified and subcultured onto a new antibiotic-amended PDA plate. $C$. lupini isolates were provided by the Culture Collection of the University of Western Brittany (UBOCC).

Plant sampling for early detection of diseases in the field. Lupin samples were collected in 2017 in 10 fields in the Loire-Atlantique department in France (5 in the north and 5 in the south of the Loire
River). Nine entire lupin plants were collected in each field every week for 5 weeks starting from 3 weeks before flowering. For each collection, fields were considered as symptomatic when symptoms were observed and asymptomatic when no symptoms were detected. When symptoms appeared in a field, they continued to be observed during the next collection dates. Leaves and stems of all samples were separated and lyophilized for $48 \mathrm{~h}$.

Fungal culture and morphological study. Morphological observations (colony color, texture, zonation, growing margin, and color of the reverse side) of a subset of nine strains (Table 1) were made on cultures grown on PDA plates incubated at room temperature $\left(\sim 20^{\circ} \mathrm{C}\right)$ under natural daylight over 2 weeks (Cannon et al. 2008). The nine strains were selected considering phylogenetic results, geographical origins, and isolation date. Observations and measurements of conidial size and shape were made by microscopic observation of spores (50 randomly chosen, ×1,000, Olympus BX61 microscope; Shinjuku) harvested after 14 days of incubation and mounted in cotton blue (Cannon et al. 2008).

The mycelium of $C$. lupini pure cultures was scraped from PDA plates after 7 to 10 days at $25^{\circ} \mathrm{C}$ with a sterile scalpel before DNA extraction with the FastDNA Spin kit (MP Biomedicals) following the manufacturer's instructions.

Multilocus phylogenetic analysis of $\boldsymbol{C}$. lupini. A phylogenetic study was performed on 117 isolates using the ITS region (White et al. 1990), partial sequence of the GAPDH gene (Guerber et al. 2003), partial sequence of the TUB2 gene (exons 3 through 6 , including introns 2 through 4) (Woudenberg et al. 2009), partial sequences of the chitin synthase 1 (CHS-1) gene (modified from Carbone and Kohn 1999), partial sequence of the actin (ACT) gene (modified from Carbone and Kohn 1999), partial sequence of the HIS3 gene (Crous et al. 2006), partial sequence of the conserved HMG box region (HMG), the intron included in the conserved HMG box region (Baroncelli et al. 2015b), and the Apn2-Mat12-1 intergenic (APN/MAT1) spacer and partial mating type gene (this study).

These regions were amplified using PCRs reactions performed in a $25-\mu l$ volume using $0.025 \mathrm{U} / \mu \mathrm{l}$ of GoTaq Flexi DNA polymerase (Promega), $1 \times$ GoTaq Flexi buffer (Promega), 25 to $50 \mathrm{ng}$ of template DNA, $0.08 \mu \mathrm{M}$ each primer, $2 \mathrm{mM} \mathrm{MgCl} 2$, and $0.2 \mathrm{mM}$ of $10 \mathrm{mM}$ dNTP mix (Promega). For GAPDH and TUB2 genes, primer concentrations were increased to $0.2 \mu \mathrm{M}$, whereas the dNTP mix concentration was decreased to $0.08 \mathrm{mM}$. A list of primers pairs and PCR conditions used in this study is reported in Table 2.

PCR products were visualized on a $1 \%(\mathrm{wt} / \mathrm{vol})$ agarose gel in $1 \times$ TBE (tris, borate, EDTA) buffer $(40 \mathrm{mM}$ Tris-acetate and $1 \mathrm{mM}$ EDTA, pH 8.0) and stained with a GelRed solution under ultraviolet (UV) light. PCR products were sent to Eurofins MWG (Ebersberg, Germany) for purification and sequencing in forward and reverse directions. ABI trace files were analyzed, and consensus sequences were generated using Geneious 10.0.6 (Biomatters; https://www. geneious.com) (Kearse et al. 2012).

The sequences obtained were aligned using MAFFT v. 7.304 online software (Katoh and Standley 2013), and they were manually checked and trimmed to optimize the alignment.

Multiple sequence alignments were exported to MEGA7 (Kumar et al. 2016), and the best-fit substitution model was calculated for each separate sequence dataset. The multilocus concatenated alignment (ITS, CHS-1, TUB2, ACT, HIS3, GAPDH, HMG, and APN/MAT1) was performed using Geneious 10.0.6. Using MrBayes 3.2.6 (Ronquist and Huelsenbeck 2003), the Markov chain Monte Carlo (MCMC) algorithm was performed to generate phylogenetic trees with Bayesian posterior probabilities for combined sequence datasets using, for each locus, the nucleotide substitution models determined by MEGA7. Four MCMC chains were run simultaneously for random trees for 5,000,000 generations. Samples were taken every 1,000 generations. The first $25 \%$ of trees were discarded as the burn-in phase of each analysis, and posterior probabilities were determined from the remaining trees. 
Table 1. Isolation details of Colletotrichum lupini strains and references used in this study (fl, flower; fr, fruit; 1, leaf; pe, petiole; po, pod; se, seed; st, stem; tw, twig)

\begin{tabular}{|c|c|c|c|c|c|c|c|}
\hline Strain & Species & Collection code & Isolate & Origin & Isolation date & Host & Organ \\
\hline $\mathrm{RB} 017^{\mathrm{a}}$ & C. tamarilloi & CBS 129954 & Tom-21 & Colombia & & Cyphomandra betacea & \\
\hline $\mathrm{RB} 018^{\mathrm{a}}$ & C. tamarilloi & CBS 129955 & Tom-12 & Colombia & 1998 & Cyphomandra betacea & $\mathrm{fl}$ \\
\hline RB020a,b & C. lupini & UBOCC-A-118135 & РT30 & Azores, Portugal & 1999 & L. albus & st \\
\hline $\mathrm{RB} 021^{\mathrm{a}}$ & C. fioriniae & CBS 129946 & PT170 & Torres vedras, Portugal & 2002 & Olea europaea & \\
\hline $\mathrm{RB} 022^{\mathrm{a}}$ & C. fioriniae & CBS 129947 & CR46 & Portugal & 2000 & Vitis vinifera & \\
\hline $\mathrm{RB} 042^{\mathrm{a}}$ & C. lupini & CBS 129944 & CMG12 & Lisbon, Portugal & 1996 & Cinnamomum zeylanicum & \\
\hline RB096 ${ }^{\mathrm{a}}$ & C. salicis & CBS 129972 & MP1 & U.S.A. & & Acer Platanoides & 1 \\
\hline $\mathrm{RB} 111^{\mathrm{a}}$ & C. fioriniae & IMI 504882 & PJ7 & New Zealand & & Fragaria $\times$ ananassa & \\
\hline $\mathrm{RB} 116^{\mathrm{a}}$ & C. lupini & & CSL 1294 & United Kigndom & & L. polyphyllus & \\
\hline RB119a & C. lupini & & G52 & Germany & & L. albus & \\
\hline $\mathrm{RB} 120^{\mathrm{a}}$ & C. lupini & & 96A649 & Australia & & L. polyphyllus & \\
\hline $\mathrm{RB} 121^{\mathrm{a}, \mathrm{b}}$ & C. lupini & IMI 504884 & HY09 & Canada & & L. albus & \\
\hline $\mathrm{RB} 122^{\mathrm{a}}$ & C. lupini & & $\mathrm{C} 3$ & Poland & & L. lateus & \\
\hline $\mathrm{RB} 123^{\mathrm{a}}$ & C. lupini & IMI 504885 & SHK788 & South Africa & & L. albus & \\
\hline $\mathrm{RB} 124^{\mathrm{a}}$ & C. lupini & & BBA 70555 & Chile & & L. albus & \\
\hline $\mathrm{RB} 125^{\mathrm{a}}$ & C. lupini & CBS 109224 & BBA 70399 & Austria & & L. albus & \\
\hline $\mathrm{RB} 127^{\mathrm{a}}$ & C. lupini & & PT702 & Spain & & Olea europaea & \\
\hline $\mathrm{RB} 147^{\mathrm{a}}$ & C. lupini & IMI 350308 & & Kent, United Kingdom & 1991 & Lupinus sp. & \\
\hline $\mathrm{RB} 151^{\mathrm{a}}$ & C. phormii & CBS 118191 & AR3787 & South Africa & 2002 & Phormium sp. & 1 \\
\hline $\mathrm{RB} 156^{\mathrm{a}}$ & C. salicis & IMI 345585 & $\begin{array}{l}\text { CSL 1044; } \\
\text { CPC } 19376\end{array}$ & New Zealand & & Fragaria $\times$ ananassa & pe \\
\hline $\mathrm{RB} 157^{\mathrm{a}}$ & C. salicis & CBS 607.94 & & Netherlands & 1994 & Salix sp. & 1 \\
\hline $\mathrm{RB} 163^{\mathrm{a}}$ & C. nymphaeae & IMI 360928 & CPC 18926 & Switzerland & & Fragaria $\times$ ananassa & $\mathrm{fr}$ \\
\hline $\mathrm{RB} 170^{\mathrm{a}}$ & Colletotrichum sp. & CBS 101611 & & Costa Rica & & fern & \\
\hline $\mathrm{RB} 172^{\mathrm{a}}$ & C. lupini & $\begin{array}{l}\text { CBS 109221; } \\
\text { UBOCC-A-117269 }\end{array}$ & BBA 70352 & Germany & & L. albus & \\
\hline $\mathrm{RB} 173^{\mathrm{a}, \mathrm{b}, \mathrm{c}}$ & C. lupini & $\begin{array}{l}\text { CBS 109225; } \\
\text { UBOCC-A-117263 }\end{array}$ & BBA 70884 & Ukraine & & L. albus & \\
\hline $\mathrm{RB} 177^{\mathrm{a}}$ & C. acutatum & CBS 112996 & $\begin{array}{r}\text { ATCC 56816; } \\
\text { STE-U } 5292\end{array}$ & Australia & 1965 & Carica papaya & $\mathrm{fr}$ \\
\hline $\mathrm{RB} 178^{\mathrm{a}}$ & C. acutatum & CBS 113008 & STE-U 4463 & South Africa & & Hakea sericea & \\
\hline RB179a & C. simmondsii & CBS 122122 & BRIP28519 & Australia & 1987 & Carica papaya & fr \\
\hline $\mathrm{RB} 183^{\mathrm{a}}$ & C. salicis & CBS 192.56 & & Germany & & Salix sp. & \\
\hline $\mathrm{RB} 184^{\mathrm{a}}$ & C. costaricensis & $\begin{array}{l}\text { CBS 211.78; } \\
\text { IMI } 309622\end{array}$ & & Costa Rica & & Coffea sp. & tw \\
\hline $\mathrm{RB} 186^{\mathrm{a}}$ & C. simmondsii & CBS 294.67 & DPI 13483 & Australia & 1959 & Carica papaya & \\
\hline $\mathrm{RB} 187^{\mathrm{a}}$ & C. acutatum & CBS 370.73 & NRCC 10088 & New Zealand & 1965 & Pinus radiata & \\
\hline $\mathrm{RB} 190^{\mathrm{a}}$ & C. nymphaeae & IMI 504889 & SA-01 & Denmark & & Fragaria $\times$ ananassa & \\
\hline $\mathrm{RB} 196^{\mathrm{a}}$ & C. abscissum & & OCO-ARC-4 & U.S.A. & & Citrus $\times$ sinensis & \\
\hline $\mathrm{RB} 197^{\mathrm{a}}$ & C. abscissum & IMI 504890 & STF-FTP-10 & U.S.A. & & Citrus $\times$ sinensis & \\
\hline $\mathrm{RB} 209^{\mathrm{a}}$ & C. orchidophilum & IMI 309357 & CPC 16815 & United Kingdom & & Phalaenopsis sp. & \\
\hline $\mathrm{RB} 210^{\mathrm{a}}$ & C. chrysanthemi & IMI 364540 & CPC 18930 & China & & Chrysanthemum coronarium & 1 \\
\hline $\mathrm{RB} 216^{\mathrm{a}}$ & C. cuscutae & IMI 304802 & CPC 18873 & Dominica & & Cuscuta sp. & \\
\hline $\mathrm{RB} 217^{\mathrm{a}, \mathrm{b}, \mathrm{c}}$ & C. lupini & IMI 375715 & CPC 19390 & Australia & 1997 & L. albus & \\
\hline $\mathrm{RB} 218^{\mathrm{a}}$ & C. paranaense & IMI 384185 & CPC 18937 & Brazil & & Caryocar brasiliense & \\
\hline $\mathrm{RB} 235^{\mathrm{a}, \mathrm{b}, \mathrm{c}}$ & C. lupini & $\begin{array}{l}\text { CBS 509.97; } \\
\text { UBOCC-A-117276 }\end{array}$ & LARS 178 & France & & L. albus & \\
\hline $\mathrm{RB} 237^{\mathrm{a}}$ & C. melonis & CBS 134730 & CPC20912 & Brazil & & Malus sp. & \\
\hline $\mathrm{RB} 238^{\mathrm{a}}$ & C. paranaense & CBS 134729 & СРC20901 & Brazil & & Malus sp. & \\
\hline $\mathrm{RB} 239^{\mathrm{a}}$ & C. abscissum & CBS 134727 & СРC20894 & Brazil & & Psidium sp. & \\
\hline $\mathrm{RB} 240^{\mathrm{a}}$ & C. paranaense & CBS 134728 & CPC20928 & Brazil & & Prunus sp. & \\
\hline $\mathrm{AB} 024^{\mathrm{a}}$ & C. lupini & UBOCC-A-118079 & & Brittany, France & 2016 & L. albus var. Orus & st-1 \\
\hline $\mathrm{AB} 025^{\mathrm{a}}$ & C. lupini & UBOCC-A-118080 & & Brittany, France & 2016 & L. albus var. Orus & st-1 \\
\hline $\mathrm{AB} 026^{\mathrm{a}}$ & C. lupini & UBOCC-A-118081 & & Brittany, France & 2016 & L. albus var. Orus & st-1 \\
\hline $\mathrm{AB} 027^{\mathrm{a}}$ & C. lupini & UBOCC-A-118082 & & Brittany, France & 2016 & Lupinus sp. & st-1 \\
\hline $\mathrm{AB} 028^{\mathrm{a}}$ & C. lupini & UBOCC-A-118083 & & Brittany, France & 2016 & Lupinus sp. & st-1 \\
\hline $\mathrm{AB} 029^{\mathrm{a}}$ & C. lupini & UBOCC-A-118084 & & Brittany, France & 2016 & Lupinus sp. & st-1 \\
\hline $\mathrm{AB} 030^{\mathrm{a}}$ & C. lupini & UBOCC-A-118085 & & Brittany, France & 2016 & Lupinus sp. & st-1 \\
\hline $\mathrm{AB} 031^{\mathrm{a}}$ & C. lupini & UBOCC-A-118086 & & Brittany, France & 2016 & Lupinus sp. & st-1 \\
\hline $\mathrm{AB} 037^{\mathrm{a}}$ & C. lupini & UBOCC-A-118087 & & Brittany, France & 2016 & Lupinus sp. & st-1 \\
\hline $\mathrm{AB} 042^{\mathrm{a}}$ & C. lupini & UBOCC-A-118088 & & Brittany, France & 2016 & Lupinus sp. & st-1 \\
\hline $\mathrm{AB} 043^{\mathrm{a}}$ & C. lupini & UBOCC-A-118089 & & Brittany, France & 2016 & Lupinus sp. & st-1 \\
\hline $\mathrm{AB} 044^{\mathrm{a}}$ & C. lupini & UBOCC-A-118090 & & Brittany, France & 2016 & L. albus var. Orus & st \\
\hline
\end{tabular}

a Strains used for phylogenetic tree study underlying for reference strains.

b Strains used for morphological diversity study.

${ }^{c}$ Strains used for in vitro growth modeling.

d Strains used for aggressiveness evaluation under optimal and suboptimal temperature study. 
Table 1. (Continued from previous page)

\begin{tabular}{|c|c|c|c|c|c|c|c|}
\hline Strain & Species & Collection code & Isolate & Origin & Isolation date & Host & Organ \\
\hline $\mathrm{AB} 045^{\mathrm{a}}$ & C. lupini & UBOCC-A-118091 & & Brittany, France & 2016 & Lupinus sp. & st-1 \\
\hline $\mathrm{AB} 046^{\mathrm{a}}$ & C. lupini & UBOCC-A-118092 & & Brittany, France & 2016 & Lupinus sp. & st-1 \\
\hline $\mathrm{AB} 047^{\mathrm{a}}$ & C. lupini & UBOCC-A-118093 & & Brittany, France & 2016 & L. albus var. Orus & st-1 \\
\hline $\mathrm{AB} 048^{\mathrm{a}}$ & C. lupini & UBOCC-A-118094 & & Brittany, France & 2016 & Lupinus sp. & st-1 \\
\hline $\mathrm{AB} 049^{\mathrm{a}}$ & C. lupini & UBOCC-A-118095 & & Brittany, France & 2016 & Lupinus sp. & st-1 \\
\hline $\mathrm{AB} 055^{\mathrm{a}}$ & C. lupini & UBOCC-A-118097 & & Brittany, France & 2016 & Lupinus sp.—-spring variety & st-1 \\
\hline $\mathrm{AB} 056^{\mathrm{a}}$ & C. lupini & UBOCC-A-118098 & & Brittany, France & 2016 & L. albus var. Energy & st-1 \\
\hline $\mathrm{AB} 057^{\mathrm{a}}$ & C. lupini & UBOCC-A-118099 & & Brittany, France & 2016 & Lupinus sp. & st \\
\hline $\mathrm{AB} 058^{\mathrm{a}}$ & C. lupini & UBOCC-A-118100 & & Brittany, France & 2016 & L. albus var. Amiga & st-1 \\
\hline $\mathrm{AB} 059^{\mathrm{a}}$ & C. lupini & UBOCC-A-118101 & & Brittany, France & 2016 & L. albus spring variety & st-1 \\
\hline $\mathrm{AB} 060^{\mathrm{a}}$ & C. lupini & UBOCC-A-118102 & & Brittany, France & 2016 & L. albus var. Amiga & st-1 \\
\hline $\mathrm{AB} 061^{\mathrm{a}}$ & C. lupini & UBOCC-A-118103 & & Brittany, France & 2016 & L. albus var. Amiga & st-1 \\
\hline $\mathrm{AB} 062^{\mathrm{a}}$ & C. lupini & UBOCC-A-118104 & & Brittany, France & 2016 & Lupinus sp.—spring variety & st-1 \\
\hline $\mathrm{AB} 063^{\mathrm{a}}$ & C. lupini & UBOCC-A-118105 & & Brittany, France & 2016 & L. albus var. Amiga & st-1 \\
\hline $\mathrm{AB} 064^{\mathrm{a}}$ & C. lupini & UBOCC-A-118106 & & Brittany, France & 2016 & L. luteus var. Mister & st-1 \\
\hline $\mathrm{AB} 065^{\mathrm{a}}$ & C. lupini & UBOCC-A-118107 & & Brittany, France & 2016 & Lupinus sp. & st-1-po \\
\hline $\mathrm{AB} 066^{\mathrm{a}}$ & C. lupini & UBOCC-A-118108 & & Brittany, France & 2016 & L. angustifolius & st-1-po \\
\hline $\mathrm{AB} 067^{\mathrm{a}}$ & C. lupini & UBOCC-A-118109 & & Brittany, France & 2016 & L. albus var. Feodora & st-1-po \\
\hline $\mathrm{AB} 068^{\mathrm{a}}$ & C. lupini & UBOCC-A-118110 & & Brittany, France & 2016 & L. albus var. Orus & st \\
\hline $\mathrm{AB} 069^{\mathrm{a}}$ & C. lupini & UBOCC-A-118111 & & Brittany, France & 2016 & L. albus var. Orus & st \\
\hline $\mathrm{AB} 070^{\mathrm{a}}$ & C. lupini & UBOCC-A-118112 & & Brittany, France & 2016 & L. albus var. Orus & st \\
\hline $\mathrm{AB} 071^{\mathrm{a}}$ & C. lupini & UBOCC-A-118113 & & Brittany, France & 2016 & L. albus var. Orus & st \\
\hline $\mathrm{AB} 072^{\mathrm{a}}$ & C. lupini & UBOCC-A-118114 & & Brittany, France & 2016 & L. albus var. Orus & st \\
\hline $\mathrm{AB} 073^{\mathrm{a}}$ & C. lupini & UBOCC-A-118115 & & Brittany, France & 2016 & L. albus var. Clovis & st \\
\hline $\mathrm{AB} 074^{\mathrm{a}}$ & C. lupini & UBOCC-A-118116 & & Brittany, France & 2016 & L. albus var. Orus & st \\
\hline $\mathrm{AB} 075^{\mathrm{a}}$ & C. lupini & UBOCC-A-118117 & & Brittany, France & 2016 & L. albus var. Orus & st \\
\hline $\mathrm{AB} 076^{\mathrm{a}}$ & C. lupini & UBOCC-A-118118 & & Brittany, France & 2016 & Lupinus sp.- -spring variety & st \\
\hline $\mathrm{AB} 077^{\mathrm{a}}$ & C. lupini & UBOCC-A-118119 & & Brittany, France & 2016 & L. albus var. Orus & st \\
\hline $\mathrm{AB} 078^{\mathrm{a}}$ & C. lupini & UBOCC-A-118120 & & Brittany, France & 2016 & L. albus var. Orus & st \\
\hline $\mathrm{AB} 079^{\mathrm{a}}$ & C. lupini & UBOCC-A-118121 & & Brittany, France & 2016 & Lupinus sp.- -spring variety & st \\
\hline $\mathrm{AB} 080^{\mathrm{a}}$ & C. lupini & UBOCC-A-118122 & & Brittany, France & 2016 & L. albus var. Orus & st \\
\hline $\mathrm{AB} 081^{\mathrm{a}}$ & C. lupini & UBOCC-A-118123 & & Brittany, France & 2016 & L. albus var. Orus & st \\
\hline $\mathrm{AB} 082^{\mathrm{a}}$ & C. lupini & UBOCC-A-118124 & & Brittany, France & 2016 & L. albus var. Orus & st \\
\hline $\mathrm{AB} 083^{\mathrm{a}}$ & C. lupini & UBOCC-A-118125 & & Brittany, France & 2016 & L. albus var. Orus & st \\
\hline $\mathrm{AB} 084^{\mathrm{a}}$ & C. lupini & UBOCC-A-118126 & & Brittany, France & 2016 & Lupinus sp. & st \\
\hline $\mathrm{AB} 085^{\mathrm{a}}$ & C. lupini & UBOCC-A-118127 & & Brittany, France & 2016 & L. albus var. Orus & st \\
\hline $\mathrm{AB} 086^{\mathrm{a}}$ & C. lupini & UBOCC-A-118128 & & Brittany, France & 2016 & L. albus var. Orus & st \\
\hline $\mathrm{AB} 087^{\mathrm{a}}$ & C. lupini & UBOCC-A-118129 & & Brittany, France & 2016 & L. albus var. Orus & st \\
\hline $\mathrm{AB} 088^{\mathrm{a}}$ & C. lupini & UBOCC-A-118130 & & Brittany, France & 2016 & L. albus var. Orus & st \\
\hline $\mathrm{AB} 089^{\mathrm{a}}$ & C. lupini & UBOCC-A-118131 & & Brittany, France & 2016 & L. albus var. Orus & st \\
\hline PN178 & C. lupini & UBOCC-A-117294 & & France & 2017 & L. albus var. Orus & st \\
\hline PN179a,b & C. lupini & UBOCC-A-118132 & & France & 2017 & L. albus var. Orus & st \\
\hline PN190a & C. lupini & UBOCC-A-118133 & & France & 2017 & Lupinus sp. & st \\
\hline PN191 ${ }^{a}$ & C. lupini & UBOCC-A-118134 & & France & 2017 & Lupinus sp. & st \\
\hline $\mathrm{RB} 219^{\mathrm{a}}$ & C. lupini & UBOCC-A-118136 & & Brittany, France & 2014 & Lupinus sp. & se-1 \\
\hline $\mathrm{RB} 220^{\mathrm{a}}$ & C. lupini & UBOCC-A-118137 & & Brittany, France & 2014 & L. albus var. Orus & st \\
\hline $\mathrm{RB} 221^{\mathrm{b}, \mathrm{c}, \mathrm{d}}$ & C. lupini & $\begin{array}{l}\text { IMI 504893; } \\
\text { UBOCC-A-117274 }\end{array}$ & & Brittany, France & 2014 & Lupinus sp. & se-st \\
\hline $\mathrm{RB} 222^{\mathrm{a}}$ & C. lupini & UBOCC-A-118138 & & Brittany, France & 2014 & Lupinus sp. & st-1 \\
\hline $\mathrm{RB} 223^{\mathrm{a}}$ & C. lupini & UBOCC-A-118139 & & Brittany, France & 2014 & & \\
\hline $\mathrm{RB} 224^{\mathrm{a}}$ & C. lupini & UBOCC-A-118140 & & Brittany, France & 2014 & L. albus var. Orus & st \\
\hline $\mathrm{RB} 225^{\mathrm{a}}$ & C. lupini & UBOCC-A-118141 & & Brittany, France & 2014 & Lupinus sp. & po \\
\hline $\mathrm{RB} 226^{\mathrm{b}, \mathrm{c}, \mathrm{d}}$ & C. lupini & UBOCC-A-117275 & & Brittany, France & 2014 & L. albus var. Lumen & po \\
\hline $\mathrm{RB} 227^{\mathrm{a}}$ & C. lupini & UBOCC-A-118142 & & Brittany, France & 2014 & L. albus var. Orus & st \\
\hline $\mathrm{RB} 228^{\mathrm{b}, \mathrm{c}}$ & C. lupini & UBOCC-A-118143 & & Brittany, France & 2014 & Lupinus sp. & st-1 \\
\hline $\mathrm{RB} 229^{\mathrm{a}}$ & C. lupini & UBOCC-A-118144 & & Brittany, France & 2014 & Lupinus sp. & st-1 \\
\hline $\mathrm{RB} 230^{\mathrm{a}}$ & C. lupini & UBOCC-A-118145 & & Brittany, France & 2013 & L. albus var. Lumen & st-1 \\
\hline $\mathrm{RB} 236^{\mathrm{a}}$ & C. lupini & UBOCC-A-118146 & & Brittany, France & 2014 & Lupinus sp. & \\
\hline $\mathrm{RB} 241^{\mathrm{a}}$ & C. lupini & UBOCC-A-118147 & & Brittany, France & 2015 & Lupinus sp. & \\
\hline $\mathrm{RB} 242^{\mathrm{a}}$ & C. lupini & UBOCC-A-118148 & & France & 2016 & Lupinus sp. & \\
\hline
\end{tabular}


The nucleotide sequences for ITS, ACT, CHS, GAPDH, HIS, HMG, TUB, and APN/MAT1 have been deposited at the NCBI website and are available with the accession numbers listed in Table 3.

Effect of temperature in vitro: Radial growth rate assessment and model fitting. Mycelial plugs from the margin of actively growing cultures of six isolates (Table 1) were placed in the center of PDA plates. The plates were then incubated at 5, 7, 10, 15, 17, 20, 25, 27, 30 , and $37^{\circ} \mathrm{C}$ in temperature-controlled incubators (KB 240; Binder $\mathrm{GmbH}$ ) (Thomas et al. 2008). Colony radius was measured daily in two perpendicular directions for a maximum of 40 days (MorinSardin et al. 2016; Nguyen Van Long et al. 2017). Three biological replicates were made for each temperature $\times$ isolate combination.

A two-step modeling approach was adopted. In the first step, radial growth as a function of incubation time was modeled with a two-phase primary model with latency for each strain and incubation temperature (Dagnas and Membré 2013) (equation 1):

$$
r_{(t)}=\left\{\begin{array}{c}
r_{0}, t \leq \lambda \\
r_{0}+\mu \cdot(t-\lambda), t>\lambda
\end{array}\right.
$$

where $r(t)$ is the radius of the mycelium (millimeters) at the time of incubation $t$ (days) and $\lambda$ is the latency (days) before growth characterized by $\mu$, the radial growth rate (millimeters per day). In this study, the radius $r(0)$ was fixed at $2.5 \mathrm{~mm}$.

In the second step, radial growth rate $\mu$ (millimeters per day) was modeled as a function of incubation temperature $(T)$ with a cardinal model (adapted from Rosso 1995) (equation 2):

$$
\begin{gathered}
\mu=\mu_{o p t}(T) \cdot C M_{n}(T) \\
C M_{N}(T)=\left\{\begin{array}{cc}
\left(T-T_{\max }\right) \cdot\left(T-T_{\min }\right)^{n} & T \leq T_{\min } \\
\frac{\left(T_{o p t}-T_{\min }\right)^{n-1} \cdot\left\{\left(T_{o p t}-T\right) \cdot\left(T-T_{o p t}\right)\right.}{T_{\min }<T<T_{\max }} & T>T_{\max } \\
\left.-\left(T_{o p t}-T_{\max }\right) \cdot\left[(n-1) \cdot T_{o p t}+T_{\min }-n \cdot T\right]\right\} &
\end{array}\right.
\end{gathered}
$$

where $T_{m i n}, T_{o p t}$, and $T_{\text {max }}$ (cardinal $T$ values) are the minimum, optimum, and maximum $T$ values, respectively; $n$ is a shape parameter $(n=2) ; \mu$ is the radial growth rate; and $\mu_{\text {opt }}$ is the value of $\mu$ when $T=T_{\text {opt }}$. Modeling was conducted with Matlab software (R2017a; Mathworks). To evaluate the model fitting performances, the coefficient of determination $\left(r^{2}\right)$ and the root mean square error (RMSE) were computed (Ratkowsky 2004).

Evaluation of in planta aggressiveness. The variety of lupin used was a spring variety named Feodora (Jouffray-Drillaud). Lupin seeds were disinfected for $1 \mathrm{~min}$ into a solution of $70 \%$ ethanol and then, rinsed three times into distilled sterile water before being placed on water agar media for 3 days in Jiffy pots (peat pellets, $41 \mathrm{~mm}$ diameter). Plants were grown at $25^{\circ} \mathrm{C}$ during day and night with $16 \mathrm{~h}$ of light, $8 \mathrm{~h}$ of darkness, and $60 \%$ humidity for 2 weeks before inoculation. Plants were watered every 2 days during the entire experiment.

Spores of RB221 and RB226, harvested from 2-week-old PDA cultures at $25^{\circ} \mathrm{C}$, were suspended into $1.5 \mathrm{ml}$ of distilled sterile water, and the concentration was adjusted to $1 \times 10^{4}$ spores per milliliter. Five microliters of the spore suspension was used to inoculate sterilized lupin boiled seeds (adapted from Saubeau et al. 2014) placed on plates of $1.3 \%(\mathrm{wt} / \mathrm{vol})$ water agar (Biomérieux). After a week at $25^{\circ} \mathrm{C}$, the final spore inoculum was prepared by shaking infected lupin seeds into 3 to $4 \mathrm{ml}$ of distilled water and adjusted to $1 \times 10^{7}$ spores per milliliter.

The pathogenicity assay at suboptimal temperature was performed using two isolates with contrasted behavior at low temperatures in vitro (i.e., RB221 and RB226 displaying different $T_{\text {min }}$ and $T_{o p t}$ ) (Table 4). These inoculations were performed with 2-week-old plantlets; at that time, plants were developed enough to observe symptoms, especially at low temperatures. At this stage, we previously noticed that a wound of the stem with a chirurgical needle before injection of the inoculum was needed to ensure the observation of disease symptoms (G. Dubrulle, unpublished data). Five microliters of inoculum $\left(1 \times 10^{7}\right.$ spores per milliliter $)$ was directly injected with a needle into the middle of the stem. For each strain tested, 10 plants were inoculated, and three biological repetitions were performed. Plantlets inoculated with water were used as negative control. Inoculated plants were grown under the same parameters as described previously and exposed to 5,10 , or $25^{\circ} \mathrm{C}$.

Symptoms were quantified and plants were collected at 0 and 7 days postinoculation (dpi) at $25^{\circ} \mathrm{C}$; at $0,7,14$, and $21 \mathrm{dpi}$ at $10^{\circ} \mathrm{C}$; and at $0,7,14,21$, and $28 \mathrm{dpi}$ at $5^{\circ} \mathrm{C}$. Aggressiveness was determined by measuring the size of the necrotic lesions and quantifying the amount of $C$. lupini DNA by qPCR using species-specific primers. One hundred milligrams of fresh stem of each plant was sampled around the inoculated or necrotic area. For each condition, 10 plants were pooled together, frozen in liquid nitrogen, and lyophilized for $48 \mathrm{~h}$ before DNA extraction. In addition, the area under the disease progress curve (AUDPC) of necrosis length or $C$. lupini DNA was also calculated. To calculate AUDPC, lesion lengths of 10 plants measured at each time were averaged for each of the three biological repetitions.

Statistical analyses were performed using RStudio software (version 3.2.5). For each studied variable (necrosis length, amount of C. lupini DNA, or AUDPC), an analysis of variance (ANOVA) was performed to study the influence of temperature, isolate, and time-point postinoculation on both lesion lenght and fungal DNA quantification.

ANOVAs were performed to identify the effect of each variable on lesion length or fungal DNA quantification. Then, a multiple comparisons test with posthoc Tukey honestly significant difference (HSD) method was performed to identify statistical groups within each variable. The level of significance was set at $\alpha=0.05$. The impact of the strain on the two measures was tested with an ANOVA at each temperature or each time point postinoculation, and the temperature effect was evaluated with an ANOVA for each strain and time postinoculation. The lesion length and fungal DNA quantification were compared by pairwise condition.

Extraction of $\boldsymbol{C}$. lupini DNA in planta. Dried stem samples were ground in a Mixer mill (Retsch; MM400) three times at 30-Hz frequency for $30 \mathrm{~s}$ either in a 50-ml stainless steel jar containing one 15-mm-diameter stainless steel ball for field samples or in 2-ml Eppendorf tubes containing a ceramic ball for inoculated plants. DNA was extracted from approximately $100 \mathrm{mg}$ of ground lupin samples from fields and $30 \mathrm{mg}$ of inoculated plants with the FastDNA Spin kit (MP Biomedicals) following the manufacturer's instructions. Quality and concentration of the DNA were determined using a UV spectrophotometer (Nanodrop1000; Thermo Scientific), and DNA was stored at $-20^{\circ} \mathrm{C}$ until use. Total DNA extracted from samples was diluted to $10 \mathrm{ng} / \mu \mathrm{l}$ final concentration for $\mathrm{qPCR}$ analysis.

qPCR conditions for $C$. lupini quantification in planta. A set of primers was designed in a conserved species-specific region of the $C$. lupini genome. The species-specific primers CLUP01-F 5'-ATGATGCTTTCTTTGGTGGCG-3' and CLUP01-R 5'-CCGGCCTGAAGACACAACG-3' (R. Baroncelli, personal communication) were tested in PCR or qPCR assays with nine $C$. lupini isolates covering the intraspecific diversity observed in this study. In addition, we checked that primers CLUP01-F and CLUP01-R did not amplify sequences from 10 closely related Colletotrichum species belonging to the Acutatum complex (namely $C$. fioriniae, $C$. godetiae, $C$. nymphaeae, $C$. rhombiforme, $C$. phormii, $C$. kinghornii, C. laticiphila, C. acutatum, C. simmondsii, and C. brisbaniense) and 3 fungal isolates not belonging to the Colletotrichum genus but isolated from lupin (Phoma pinodella, Truncatella angustata, and Botrytis cinerea). The 25- $\mu$ l PCR mix consisted of $1 \times$ GoTaq buffer, $0.2 \mathrm{mmol}$ of dNTP, $0.2 \mu \mathrm{M}$ each primer, $2 \mathrm{mM} \mathrm{MgCl}_{2}, 1.25 \mathrm{U}$ of GoTaq polymerase (Promega), and $1 \mu \mathrm{l}$ 
of template DNA. The PCR assay started by initial denaturation at $95^{\circ} \mathrm{C}$ for 5 min followed by 35 cycles at $95^{\circ} \mathrm{C}$ for $1 \mathrm{~min}, 68^{\circ} \mathrm{C}$ for $1 \mathrm{~min}$, and $72^{\circ} \mathrm{C}$ for $30 \mathrm{~s}$ and a final extension step at $72^{\circ} \mathrm{C}$ for $3 \mathrm{~min}$. PCR products were verified on a $2 \%(\mathrm{wt} / \mathrm{vol})$ agarose gel in $1 \times$ TAE (tris, acetate, EDTA) buffer ( $40 \mathrm{mM}$ Tris-acetate and $1 \mathrm{mM}$ EDTA, $\mathrm{pH}$ 8.0) and visualized after staining with a GelRed solution under UV light.

All qPCR assays were performed on a CFX96 Real-Time PCR System (Bio-Rad) in a 20- $\mu$ l reaction volume containing $10 \mu \mathrm{l}$ of SsoFast EvaGreen Supermix (Bio-Rad), $500 \mathrm{nM}$ species-specific primers CLUP01-F and CLUP01-R, $7 \mu l$ of DNAse-free water, and $1 \mu l$ of total DNA sample diluted to $10 \mathrm{ng} / \mu \mathrm{l}$. The following thermal program was applied: an initial denaturation step of $98^{\circ} \mathrm{C}$ for $2 \mathrm{~min}$ followed by 40 amplification cycles of a 5 -s denaturing step $\left(98^{\circ} \mathrm{C}\right)$ and 3 -s annealing-extension step $\left(68^{\circ} \mathrm{C}\right)$. The analysis of the melting curve was used to check the absence of nonspecific PCR amplification and dimer formation. The melting curve was generated with a temperature gradient of $0.5^{\circ} \mathrm{C} / \mathrm{s}$ from 65 to $95^{\circ} \mathrm{C}$. The melting temperature obtained with $C$. lupini amplicons was $81^{\circ} \mathrm{C}$. In addition, each run included no template controls, which never amplified or at cycle threshold $\left(\mathrm{C}_{\mathrm{T}}\right)>39$. Quantification of $C$. lupini was expressed in nanograms of fungal DNA in $10 \mathrm{ng}$ of total DNA. Negative controls were not shown in the analysis.

The fungal DNA extracted from pure cultures of $C$. lupini isolate RB221 was used to prepare a 10-fold dilution series of five concentration points starting with $10 \mathrm{ng} / \mu \mathrm{l}$. These dilutions series are hereafter referred to as "fungal DNA series." To take into account the presence of plant DNA, additional dilution series were prepared by mixing the fungal DNA series in a lupin background DNA concentration fixed at $10 \mathrm{ng} / \mu \mathrm{l}$ (hereafter referred to as "background DNA series"). The standard curve used to quantify fungal DNA in the lupin matrices corresponded to the 10- to $10^{-3}-\mathrm{ng} / \mu \mathrm{l}$ range of fungal DNA all mixed with $10 \mathrm{ng} / \mu \mathrm{l}$ of lupin DNA. The $\mathrm{C}_{\mathrm{T}}$ values were obtained by the CFX Manager Software version 1.6 (Bio-Rad). To calculate the amplification efficacy (AE) of each standard curve, $C_{T}$ values were plotted against $\log _{10}$ (fungal DNA), and the slope of the linear curves was determined using the following equation:

$$
\mathrm{AE}=\left(10^{(-1 / \text { slope })}\right)-1
$$

The average PCR efficacy of the standard curves always ranged between 90 and $105 \%$, whereas the $R^{2}$ of standard curves was systematically $>0.98$. The $C_{\mathrm{T}}$ values of our standard curves ranged between $23.5 \pm 0.4$ and $36.8 \pm 0.5$.

\section{Results}

Phylogenetic study among C. lupini isolates. In this study, 116 isolates were used, including 71 isolates collected in western France between 2014 and 2017, 16 reference strains of C. lupini, and 28

Table 2. List of primer pairs and PCR conditions used for this study

\begin{tabular}{|c|c|c|c|c|c|c|c|c|}
\hline Locus & Name & Primers & Primer sequences & Step & Time & $\begin{array}{l}\text { Temp. } \\
\left({ }^{\circ} \mathrm{C}\right)\end{array}$ & Cycles & Reference \\
\hline \multirow[t]{5}{*}{ ITS } & \multirow{5}{*}{$\begin{array}{l}\text { Internal transcribed } \\
\text { spacer }\end{array}$} & ITS5 & \multirow{5}{*}{$\begin{array}{l}\text { GGAAGTAAAAGTCGTAACAAGG } \\
\text { TCCGCTTATTGATATGC }\end{array}$} & Denaturation & $5 \min$ & 95 & 1 & \multirow[t]{5}{*}{ White et al. (1990) } \\
\hline & & \multirow[t]{4}{*}{ ITS4 } & & \multirow[t]{3}{*}{ Amplification } & $1 \mathrm{~min}$ & 95 & 30 & \\
\hline & & & & & $1 \mathrm{~min}$ & 55 & & \\
\hline & & & & & $1 \mathrm{~min}$ & 72 & & \\
\hline & & & & Final extension & $10 \mathrm{~min}$ & 72 & 1 & \\
\hline \multirow[t]{5}{*}{ GAPDH } & \multirow{5}{*}{$\begin{array}{l}\text { Glyceraldehyde-3- } \\
\text { phosphate } \\
\text { dehydrogenase }\end{array}$} & GDF1 & GCCGTCAACGACCCCTTCATTGA & Denaturation & $5 \mathrm{~min}$ & 94 & 1 & \multirow{5}{*}{$\begin{array}{l}\text { Guerber et al. } \\
\text { (2003) }\end{array}$} \\
\hline & & \multirow[t]{4}{*}{ GDR1 } & \multirow[t]{4}{*}{ GGGTGGAGTCGTACTTGAGCATGT } & Amplification & $30 \mathrm{~s}$ & 94 & 35 & \\
\hline & & & & & $30 \mathrm{~s}$ & 60 & & \\
\hline & & & & & $30 \mathrm{~s}$ & 72 & & \\
\hline & & & & Final extension & $7 \mathrm{~min}$ & 72 & 1 & \\
\hline \multirow[t]{5}{*}{ TUB2 } & \multirow[t]{5}{*}{$\beta$-tubulin 2} & $\mathrm{BT} 2 \mathrm{Fd}$ & GTBCACCTYCARACCGGYCARTG & Denaturation & $2 \min$ & 95 & 1 & \multirow{5}{*}{$\begin{array}{l}\text { Woudenberg et al. } \\
\text { (2009) }\end{array}$} \\
\hline & & \multirow[t]{4}{*}{ BT4R } & \multirow[t]{4}{*}{ CCRGAYTGRCCRAARACRAAGTTGTC } & Amplification & $1 \mathrm{~min}$ & 94 & 30 & \\
\hline & & & & & $1 \mathrm{~min}$ & 67 & & \\
\hline & & & & & $1 \mathrm{~min}$ & 72 & & \\
\hline & & & & Final extension & $5 \min$ & 72 & 1 & \\
\hline \multirow[t]{5}{*}{ CHS-1 } & \multirow[t]{5}{*}{ Chitin synthase 1} & CHS-79F & TGGGGCAAGGATGCCTGGAAGAAG & Denaturation & $2 \mathrm{~min}$ & 95 & 1 & \multirow{5}{*}{$\begin{array}{c}\text { Modified from } \\
\text { Carbone and } \\
\text { Kohn (1999) }\end{array}$} \\
\hline & & \multirow[t]{4}{*}{ CHS-354R } & \multirow[t]{4}{*}{ TGGAAGAACCATCTGTGGGAGTTG } & \multirow{3}{*}{ Amplification } & $1 \mathrm{~min}$ & 95 & \multirow{3}{*}{40} & \\
\hline & & & & & $30 \mathrm{~s}$ & 62 & & \\
\hline & & & & & $20 \mathrm{~s}$ & 72 & & \\
\hline & & & & Final extension & $5 \mathrm{~min}$ & 72 & 1 & \\
\hline \multirow[t]{5}{*}{$\mathrm{ACT}$} & Actin & ACT-512F & ATGTGCAAGGCCGGTTTCGC & Denaturation & $2 \min$ & 95 & 1 & Modified from \\
\hline & & ACT-783R & TAGGAGTCCTTCTGACCCAT & Amplification & $1 \mathrm{~min}$ & 95 & 40 & Carbone and \\
\hline & & & & & $30 \mathrm{~s}$ & 57 & & Kohn (1999) \\
\hline & & & & & $25 \mathrm{~s}$ & 72 & & \\
\hline & & & & Final extension & $5 \mathrm{~min}$ & 72 & 1 & \\
\hline HIS3 & Histone $\mathrm{H} 3$ & CYLH3Fext & AGTCCACTGGTGGCAAGGC & Denaturation & $2 \min$ & 95 & 1 & Crous et al. (2006) \\
\hline & & CYLH3R & AGCTGGATGTCCTTGGACTG & Amplification & $1 \mathrm{~min}$ & 95 & 40 & \\
\hline & & & & & $30 \mathrm{~s}$ & 57 & & \\
\hline & & & & & $25 \mathrm{~s}$ & 72 & & \\
\hline & & & & Final extension & $5 \mathrm{~min}$ & 72 & 1 & \\
\hline HMG & HMG box region & HMGacuF2 & TACCGCAGCGACTACCAAGC & Denaturation & $5 \mathrm{~min}$ & 95 & 1 & Baroncelli et al. \\
\hline & & HMGacuR & TCTTGTGGCGCTCCTTG & Amplification & $1 \mathrm{~min}$ & 95 & 40 & $(2015 b)$ \\
\hline & & & & & $1 \mathrm{~min}$ & 55 & & \\
\hline & & & & & $30 \mathrm{~s}$ & 72 & & \\
\hline & & & & Final extension & $20 \mathrm{~min}$ & 72 & 1 & \\
\hline APN/ & Apn2-Mat1-2-1 & Apnmat1F & GCGAAAGCCTACAAGGAGCG & Denaturation & $5 \mathrm{~min}$ & 95 & 1 & This study \\
\hline MAT1 & intergenic & Apnmat1R & TGGTCAAAGTTCAACCTGGG & Amplification & $1 \mathrm{~min}$ & 95 & 40 & \\
\hline & & & & & $1 \mathrm{~min}$ & 55 & & \\
\hline & & & & & $20 \mathrm{~s}$ & 72 & & \\
\hline & & & & Final extension & $20 \mathrm{~min}$ & 72 & 1 & \\
\hline
\end{tabular}


Table 3. GenBank accession numbers for internal transcribed spacer (ITS), glyceraldehyde-3-phosphate dehydrogenase (GAPDH), chitin synthase 1 (CHS-1), histone H3 (HIS3), actin (ACT), $\beta$-tubulin 2 (TUB2), HMG box region (HMG), and Apn2-Mat1-2-1 intergenic (APN/MAT1) ${ }^{\mathrm{a}}$

\begin{tabular}{|c|c|c|c|c|c|c|c|c|c|}
\hline Strain & ITS & GAPDH & CHS-1 & HIS3 & ACT & TUB2 & HMG & APN/MAT1 & References \\
\hline RB017 & JQ948188 & JQ948518 & JQ948849 & JQ949179 & JQ949509 & JQ949839 & KM251976 & MK478306 & $\begin{array}{l}\text { Damm et al. (2012); } \\
\text { Baroncelli et al. (2015b) }\end{array}$ \\
\hline RB018 & JQ948189 & JQ948519 & JQ948850 & JQ949180 & JQ949510 & JQ949840 & KM251977 & MK478307 & $\begin{array}{l}\text { Damm et al. (2012); } \\
\text { Baroncelli et al. (2015b) }\end{array}$ \\
\hline RB020 & MK463722 & KM252117 & MK463771 & MK463798 & MK478159 & MK478186 & KM251979 & MK478308 & Baroncelli et al. (2015b) \\
\hline RB021 & JQ948342 & JQ948672 & JQ949003 & JQ949333 & JQ949663 & JQ949993 & MK478211 & & Damm et al. (2012) \\
\hline RB022 & JQ948343 & JQ948673 & JQ949004 & JQ949334 & JQ949664 & JQ949994 & KM251980 & MK478309 & $\begin{array}{l}\text { Damm et al. (2012); } \\
\text { Baroncelli et al. (2015b) }\end{array}$ \\
\hline RB042 & MH865693 & JQ948508 & JQ948839 & JQ949169 & JQ949499 & JQ949829 & MK478212 & MK478310 & $\begin{array}{l}\text { Damm et al. (2012); } \\
\text { Vu et al. (2019) }\end{array}$ \\
\hline RB096 & JQ948466 & JQ948797 & JQ949127 & JQ949457 & JQ949787 & JQ950117 & KM252052 & MK478311 & $\begin{array}{l}\text { Damm et al. (2012); } \\
\text { Baroncelli et al. (2015b) }\end{array}$ \\
\hline RB111 & KT153562 & KT153552 & KT153547 & KT153557 & KT153542 & KT153567 & KM252057 & MK478312 & $\begin{array}{l}\text { Damm et al. (2012); } \\
\text { Baroncelli et al. (2015b) }\end{array}$ \\
\hline RB116 & MK463723 & KM252194 & MK463772 & MK463799 & MK478160 & KM251944 & KM252059 & MK478313 & Baroncelli et al. (2015b) \\
\hline RB119 & MK463724 & MK463748 & MK463773 & MK463800 & MK478161 & MK478187 & MK478213 & MK478314 & \\
\hline RB120 & MK463725 & MK463749 & MK463774 & MK463801 & MK478162 & MK478188 & MK478214 & MK478315 & \\
\hline RB121 & KJ018635 & KJ018659 & MK463775 & MK463802 & MK478163 & MK478189 & KM252062 & MK478316 & Baroncelli et al. (2015b) \\
\hline RB122 & MK463726 & MK463750 & MK463776 & MK463803 & MK478164 & MK478190 & MK478215 & MK478317 & \\
\hline RB123 & MK463727 & MK463751 & MK463777 & MK463804 & MK478165 & MK478191 & MK478216 & MK478318 & \\
\hline RB124 & MK463728 & MK463752 & MK463778 & MK463805 & MK478166 & MK478192 & MK478217 & MK478319 & \\
\hline RB125 & JQ948172 & JQ948502 & JQ948833 & JQ949163 & JQ949493 & JQ949823 & MK478218 & MK478320 & Damm et al. (2012) \\
\hline RB127 & MK463729 & MK463753 & MK463779 & MK463806 & MK478167 & MK478193 & MK478219 & MK478321 & \\
\hline RB147 & MK463730 & KM252203 & MK463780 & MK463807 & MK478168 & KM251951 & KM252079 & MK478322 & Baroncelli et al. (2015b) \\
\hline RB151 & JQ948453 & JQ948784 & JQ949114 & JQ949444 & JQ949774 & JQ950104 & KM252082 & MK478323 & $\begin{array}{l}\text { Damm et al. (2012); } \\
\text { Baroncelli et al. (2015b) }\end{array}$ \\
\hline RB156 & JQ948476 & JQ948807 & JQ949137 & JQ949467 & JQ949797 & JQ950127 & KM252084 & MK478324 & $\begin{array}{l}\text { Damm et al. (2012); } \\
\text { Baroncelli et al. (2015b) }\end{array}$ \\
\hline RB157 & JQ948460 & JQ948791 & JQ949121 & JQ949451 & JQ949781 & JQ950111 & KM252085 & MK478325 & $\begin{array}{l}\text { Damm et al. (2012); } \\
\text { Baroncelli et al. (2015b) }\end{array}$ \\
\hline RB163 & JQ948243 & JQ948573 & JQ948904 & JQ949234 & JQ949564 & JQ949894 & KM252091 & MK478326 & $\begin{array}{l}\text { Damm et al. (2012); } \\
\text { Baroncelli et al. (2015b) }\end{array}$ \\
\hline RB170 & JQ948196 & JQ948526 & JQ948857 & JQ949187 & JQ949517 & JQ949847 & KM252095 & MK478327 & $\begin{array}{l}\text { Damm et al. (2012); } \\
\text { Baroncelli et al. (2015b) }\end{array}$ \\
\hline RB172 & JQ948169 & JQ948499 & JQ948830 & JQ949160 & JQ949490 & JQ949820 & MK478220 & MK478328 & Damm et al. (2012) \\
\hline RB173 & JQ948155 & JQ948485 & JQ948816 & JQ949146 & JQ949476 & JQ949806 & KM252096 & MK478329 & $\begin{array}{l}\text { Damm et al. (2012); } \\
\text { Baroncelli et al. (2015b) }\end{array}$ \\
\hline RB177 & JQ005776 & JQ948677 & JQ005797 & JQ005818 & JQ005839 & JQ005860 & MK478221 & MK478330 & Damm et al. (2012) \\
\hline RB178 & JQ948396 & JQ948727 & JQ949057 & JQ949387 & JQ949717 & JQ950047 & MK478222 & MK478331 & Damm et al. \\
\hline RB179 & JQ948276 & JQ948606 & JQ948937 & JQ949267 & JQ949597 & JQ949927 & KM252099 & MK478332 & $\begin{array}{l}\text { Damm et al. (2012); } \\
\text { Baroncelli et al. (2015b) }\end{array}$ \\
\hline RB183 & JQ948462 & JQ948793 & JQ949123 & JQ949453 & & JQ950113 & MK478223 & & Damm et al. (2012) \\
\hline RB184 & JQ948181 & JQ948511 & JQ948842 & JQ949172 & JQ949502 & JQ949832 & KM252102 & MK478333 & $\begin{array}{l}\text { Damm et al. (2012); } \\
\text { Baroncelli et al. (2015b) }\end{array}$ \\
\hline RB186 & JQ948277 & JQ948607 & JQ948938 & JQ949268 & JQ949598 & JQ949928 & KM252104 & MK478334 & $\begin{array}{l}\text { Damm et al. (2012); } \\
\text { Baroncelli et al. (2015b) }\end{array}$ \\
\hline RB187 & JQ948351 & JQ948682 & JQ949012 & JQ949342 & JQ949672 & JQ950002 & MK478224 & MK478335 & Damm et al. (2012) \\
\hline RB190 & KT153561 & KT153551 & KT153546 & KT153556 & KT153541 & KT153566 & MK478225 & MK478336 & Bragança et al. (2016) \\
\hline RB196 & KT153559 & KT153549 & KT153544 & KT153554 & KT153539 & KT153564 & KM252107 & MK478337 & $\begin{array}{l}\text { Baroncelli et al. (2015b); } \\
\text { Bragança et al. (2016) }\end{array}$ \\
\hline RB197 & KT153558 & KT153548 & KT153543 & KT153553 & KT153538 & KT153563 & KM252108 & MK478338 & $\begin{array}{c}\text { Baroncelli et al. (2015b); } \\
\text { Bragança et al. (2016) }\end{array}$ \\
\hline RB209 & JQ948153 & JQ948483 & JQ948814 & JQ949144 & & JQ949804 & MK478226 & MK478339 & Damm et al. (2012) \\
\hline RB210 & JQ948273 & JQ948603 & JQ948934 & JQ949264 & JQ949594 & JQ949924 & MK478227 & & Damm et al. (2012) \\
\hline RB216 & JQ948195 & JQ948525 & JQ948856 & JQ949186 & JQ949516 & JQ949846 & MK478228 & MK478340 & Damm et al. (2012) \\
\hline RB217 & JQ948161 & JQ948491 & JQ948822 & JQ949152 & JQ949482 & JQ949812 & MK478229 & MK478341 & Damm et al. (2012) \\
\hline RB218 & JQ948191 & JQ948521 & JQ948852 & JQ949182 & JQ949512 & JQ949842 & MK478230 & MK478342 & Damm et al. (2012) \\
\hline RB235 & JQ948159 & JQ948489 & JQ948820 & JQ949150 & JQ949480 & JQ949810 & MK478243 & MK478355 & Damm et al. (2012) \\
\hline RB237 & KC204997 & KC205031 & KC205048 & KC205007 & KC205082 & KC205065 & MK478245 & MK478357 & Bragança et al. (2016) \\
\hline RB238 & KC204992 & & & & & & & & \\
\hline RB239 & KC204988 & KC205022 & & & & & MK478247 & & Bragança et al. (2016) \\
\hline RB240 & KC205002 & KC205036 & KC205053 & KC205019 & KC205087 & KC205070 & MK478248 & MK478360 & Bragança et al. (2016) \\
\hline $\mathrm{AB} 024$ & & & & & & & & & \\
\hline $\mathrm{AB} 025$ & & & & & & & & MK478251 & \\
\hline AB026 & & & & & & & & MK478252 & \\
\hline AB027 & & & & & & & & MK478253 & \\
\hline AB028 & MK463719 & MK463745 & MK463768 & MK463795 & MK478156 & MK478183 & MK478208 & MK478254 & \\
\hline
\end{tabular}

a Those in bold type refer to accession numbers newly determined in this study. 
Table 3. (Continued from previous page)

\begin{tabular}{|c|c|c|c|c|c|c|c|c|c|}
\hline Strain & ITS & GAPDH & CHS-1 & HIS3 & ACT & TUB2 & HMG & APN/MAT1 & References \\
\hline AB029 & MK463720 & MK463746 & MK463769 & MK463796 & MK478157 & MK478184 & MK478209 & MK478255 & \\
\hline AB030 & & & & & & & & MK478256 & \\
\hline AB031 & & & & & & & & MK478257 & \\
\hline AB037 & & & & & & & & MK478258 & \\
\hline AB042 & & & & & & & & MK478259 & \\
\hline AB043 & & & & & & & & MK478260 & \\
\hline AB044 & & & & & & & & MK478261 & \\
\hline AB045 & & & & & & & & MK478262 & \\
\hline AB046 & & & & & & & & MK478263 & \\
\hline AB047 & & & & & & & & MK478264 & \\
\hline AB048 & & & & & & & & MK478265 & \\
\hline AB049 & & & & & & & & MK478266 & \\
\hline AB055 & & & & & & & & MK478267 & \\
\hline AB056 & MK463721 & MK463747 & MK463770 & MK463797 & MK478158 & MK478185 & MK478210 & MK478268 & \\
\hline AB057 & & & & & & & & MK478269 & \\
\hline AB058 & & & & & & & & MK478270 & \\
\hline AB059 & & & & & & & & MK478271 & \\
\hline AB060 & & & & & & & & MK478272 & \\
\hline AB061 & & & & & & & & MK478273 & \\
\hline AB062 & & & & & & & & MK478274 & \\
\hline AB063 & & & & & & & & MK478275 & \\
\hline AB064 & & & & & & & & MK478276 & \\
\hline AB065 & & & & & & & & MK478277 & \\
\hline AB066 & & & & & & & & MK478278 & \\
\hline AB067 & & & & & & & & MK478279 & \\
\hline AB068 & & & & & & & & MK478280 & \\
\hline AB069 & & & & & & & & MK478281 & \\
\hline AB070 & & & & & & & & MK478282 & \\
\hline AB071 & & & & & & & & MK478283 & \\
\hline AB072 & & & & & & & & MK478284 & \\
\hline AB073 & & & & & & & & MK478285 & \\
\hline AB074 & & & & & & & & MK478286 & \\
\hline AB075 & & & & & & & & MK478287 & \\
\hline AB076 & & & & & & & & MK478288 & \\
\hline AB077 & & & & & & & & MK478289 & \\
\hline AB078 & & & & & & & & MK478290 & \\
\hline AB079 & & & & & & & & MK478291 & \\
\hline AB080 & & & & & & & & MK478292 & \\
\hline AB081 & & & & & & & & MK478293 & \\
\hline AB082 & & & & & & & & MK478294 & \\
\hline AB083 & & & & & & & & MK478295 & \\
\hline AB084 & & & & & & & & MK478296 & \\
\hline AB085 & & & & & & & & MK478297 & \\
\hline AB086 & & & & & & & & MK478298 & \\
\hline AB087 & & & & & & & & MK478299 & \\
\hline AB088 & & & & & & & & MK478300 & \\
\hline AB089 & & & & & & & & MK478301 & \\
\hline PN178 & & & & & & & & MK478302 & \\
\hline PN179 & & & & & & & & MK478303 & \\
\hline PN190 & & & & & & & & MK478304 & \\
\hline PN191 & & & & & & & & MK478305 & \\
\hline RB219 & MK463731 & MK463754 & MK463781 & MK463808 & MK478169 & MK478194 & MK478231 & MK478343 & \\
\hline RB220 & MK463732 & MK463755 & MK463782 & MK463809 & MK478170 & MK478195 & MK478232 & MK478344 & \\
\hline RB221 & MK463733 & MK463756 & MK463783 & MK463810 & MK478171 & MK478196 & MK478233 & MK478345 & \\
\hline RB222 & MK463734 & MK463757 & MK463784 & MK463811 & MK478172 & MK478197 & MK478234 & MK478346 & \\
\hline RB223 & MK463735 & MK463758 & MK463785 & MK463812 & MK478173 & MK478198 & MK478235 & MK478347 & \\
\hline RB224 & MK463736 & MK463759 & MK463786 & MK463813 & MK478174 & MK478199 & MK478236 & MK478348 & \\
\hline RB225 & MK463737 & MK463760 & MK463787 & MK463814 & MK478175 & MK478200 & MK478237 & MK478349 & \\
\hline RB226 & MK463738 & MK463761 & MK463788 & MK463815 & MK478176 & MK478201 & MK478238 & MK478350 & \\
\hline RB227 & MK463739 & MK463762 & MK463789 & MK463816 & MK478177 & MK478202 & MK478239 & MK478351 & \\
\hline RB228 & MK463740 & MK463763 & MK463790 & MK463817 & MK478178 & MK478203 & MK478240 & MK478352 & \\
\hline RB229 & MK463741 & MK463764 & MK463791 & MK463818 & MK478179 & MK478204 & MK478241 & MK478353 & \\
\hline RB230 & MK463742 & MK463765 & MK463792 & MK463819 & MK478180 & MK478205 & MK478242 & MK478354 & \\
\hline RB236 & MK463743 & MK463766 & MK463793 & MK463820 & MK478181 & MK478206 & MK478244 & MK478356 & \\
\hline RB241 & MK463744 & MK463767 & MK463794 & MK463821 & MK478182 & MK478207 & MK478249 & MK478361 & \\
\hline RB242 & & & & & & & & MK478362 & \\
\hline
\end{tabular}


reference strains belonging to other species of the CAsc and an outgroup C. orchidophilum (Table 1). Phylogenetic analyses based on eight different loci was first performed on 63 isolates (ITS, ACT, CHS, GAPDH, HIS, HMG, TUB, and APN/MAT1). Because APN/MAT1 showed the highest variability, it was the only locus used to characterize the additional 54 strains. All isolates collected in western France between 2014 and 2017 from infected lupin plants belonged solely to the $C$. lupini species. The molecular analysis of 87 C. lupini isolates (28 strains from 14 species belonging to the CAsc and using $C$. orchidophilum as an outgroup) was performed on a sequence alignment with 2,124 characters, of which 1,591 were conserved, 303 were parsimony informative, and 208 were singleton. The loci boundaries were ITS: 1 to 500, CHS-1: 501 to 763 , TUB2: 764 to 1,255 , ACT: 1,256 to 1,496 , HIS3: 1,497 to 1,875 , and GAPDH: 1,876 to 2,124 . Based on the multilocus molecular analysis, the $87 \mathrm{C}$. lupini isolates belonged to two different groups: isolates RB121, RB173, and RB235 belonged to group I, whereas the other isolates were clustered together (Fig. 1).

Morphological diversity. Morphological diversity was analyzed on a subset of nine strains, including strains of group I and group II as well as isolates from both our collection and reference collections (Table 1).

On PDA, all isolates produced more or less dark flat mycelia with an entire margin; surface was buff to gray covered with felty to woolly pale gray aerial mycelium, and reverse was buff to dark brown with a pale regular margin for some strains (RB173, RB235, RB121, and PN179). Radial sulcate appeared on RB173, PN179, and RB235 (Fig. 2A).

Melanized appresorial structures were observed on PDA for RB221, PN179, and RB228 (Fig. 2B).

In freshly isolated strains, conidia were produced in small orange masses. However, conidiomata were no longer observed along subcultures, and conidia production was substantially reduced except for RB235, which continued to produce a prolific amount of conidia compared with the other strains. For all strains, conidia were typical of C. acutatum described previously (Nirenberg et al. 2002). Most conidia showed a biguttulate aspect with a rounded extremity while the other was slightly pointed (Fig. $2 \mathrm{C}$ and D). For all strains, the width and length of conidia were examined, ranging from 3.5 to $4.5 \mu \mathrm{m}$ (mean 4.1) and from 9 to $15 \mu \mathrm{m}$ (mean 12.5), respectively.

Interestingly, after 35 days, microsclerotia were observed for RB121 when challenged to either itself, PN179, RB226, or RB228; for RB228 when confronted to either itself or RB121; or for RB217 and PN179 when confronted to RB173 (Fig. 2E).

Physiological diversity in vitro: Growth kinetics and effect of temperature. Growth kinetics of six $C$. lupini strains could be divided into two distinct phases: a lag phase followed by a constant radial growth of the mycelium. In optimal conditions for growth of each fungus, lag phases were relatively short, whereas growth rates were high at the low temperature tested (data not shown). Between minimal and optimal growth temperature, lag phases were longer, and growth rates were lower.

For all of the tested strains, the $\mu$ parameter increased as the temperature increased from 5 to $25^{\circ} \mathrm{C}$ and then, decreased at higher temperatures.

The minimal growth temperatures were $5^{\circ} \mathrm{C}$ for $\mathrm{RB} 221$, $\mathrm{RB} 226, \mathrm{RB} 228$, and $\mathrm{RB} 235$ and $7^{\circ} \mathrm{C}$ for RB173 and RB217. At $5^{\circ} \mathrm{C}$, the observed growth rate was too low and could be modeled only for the strain RB228. For all the strains tested, the maximum temperature for which growth was observed was $30^{\circ} \mathrm{C}$. The secondary model (equation 2) was fitted to describe growth rate dependence as a function of temperature (ranging from 5 to $37^{\circ} \mathrm{C}$ ) for all strains (Fig. 3). Residual variability between predictive and observed values of growth was low (RMSE values ranged from 1.9 to $2.7 \mathrm{~mm} /$ day), and the coefficient of determination $\left(r^{2}\right)$ values ranged from 0.90 to 0.95 for each strain. The estimated values of the parameters from the model were $T_{\text {min }}$ varying from -4.2 to $1.3^{\circ} \mathrm{C}, T_{o p t}$ from 23.7 to $25.6^{\circ} \mathrm{C}$, and $T_{\max }$ from 30.6 to $31.8^{\circ} \mathrm{C}$ (Table 4 ). In addition, $\mu_{o p t}$ ranged between $3.09 \pm 0.06 \mathrm{~mm} /$ day (strain RB042) and $3.80 \pm 0.13 \mathrm{~mm} /$ day (strain RB228) (Table 4).

Evaluation of in planta aggressiveness under optimal and suboptimal growth conditions. The effect of repetitions or twoway interactions between repetitions and any other factor (temperature, strain, or time postinoculation) was not significant for both necrotic lesion length and $C$. lupini DNA. When comparing lesion length of plants inoculated with either RB221 or RB226 and incubated at either 5,10 , or $25^{\circ} \mathrm{C}$ for 7 days, a significant temperature effect was found $(P<0.001)$, whereas no significant strain effect was noticed $(P=0.582)$. Lesion length was thus significantly higher at $25^{\circ} \mathrm{C}$ (mean lesion length: $29.9 \pm 3.2 \mathrm{~mm}$ ) than at both 5 and $10^{\circ} \mathrm{C}$ (mean lesion length: $0.08 \pm 0.1 \mathrm{~mm}$ ). At $7 \mathrm{dpi}$ at $10^{\circ} \mathrm{C}(P=0.005)$, the amount of DNA from RB226 (mean: 3.07 $\pm 0.30 \mathrm{ng}$ ) was significantly higher than the amount of DNA from RB221 (mean: $1.17 \pm 0.52 \mathrm{ng}$ ). In addition, the level of fungal DNA was significantly higher at $10^{\circ} \mathrm{C}$ than at $5^{\circ} \mathrm{C}$ independently of the strain $(P=0.049)$ (Fig. 4B).

When comparing data obtained at 5 and $10^{\circ} \mathrm{C}$ over a 21 -day period, lesion length significantly varied according to the temperature $(P<0.001)$ and the strain $(P<0.001)$. At both 14 and 21 dpi, a bigger necrosis was measured at $10^{\circ} \mathrm{C}$ or when inoculated with $\mathrm{RB} 226$ (Fig. 4A).

Field detection of $\boldsymbol{C}$. lupini. C. lupini DNA was quantified in winter and spring lupin fields over the plant growth (Table 5). Of the 47 samples collected, $C$. lupini was quantified in six samples above the limit of quantification $\left(10^{-3} \mathrm{ng}\right.$ of DNA), although all at a very low level (between $10^{-3}$ and $5.10^{-3} \mathrm{ng}$ of DNA). Interestingly, $C$. lupini DNA was detected in four out of six asymptomatic samples, which suggested that the primers tested may enable the early detection of $C$. lupini in the field, before the appearance of symptoms.

\section{Discussion}

C. lupini has been frequently misidentified as G. lupines (Bondar 1912), G. lupinicola (Seymour 1929), or G. cingulata as the teleomorph of C. gloeosporioides (Weimer 1943, 1951, 1952; Wells and Bell 1969; Wells and Forbes 1967) or C. acutatum. The study we conducted first aimed at determining taxonomic diversity among 71 isolated strains from lupin with anthracnose symptoms using a multilocus sequencing method of eight loci, including locus APN/ MAT1, which was used for the first time to characterize CAsc phylogeny. We clearly confirmed that our collection of 71 isolates from infected lupin plants belonged to the $C$. lupini species, suggesting that lupin anthracnose was exclusively associated with $C$. lupini. However, $C$. lupini strains are not exclusively isolated from the Lupinus genus. Among the strains used as reference to build the phylogenetic tree, RB042

Table 4. Cardinal value of the eight strains of Colletotrichum lupini obtained by the secondary modeling ${ }^{\mathrm{a}}$

\begin{tabular}{lccccc}
\hline Strains & $\boldsymbol{T}_{\boldsymbol{m i n}}\left({ }^{\circ} \mathbf{C}\right)$ & $\boldsymbol{T}_{\text {opt }}\left({ }^{\circ} \mathbf{C}\right)$ & $\boldsymbol{T}_{\boldsymbol{m a x}}\left({ }^{\circ} \mathbf{C}\right)$ & $\boldsymbol{\mu}_{\text {opt }}(\mathbf{m m} / \mathbf{d a y})$ & $\boldsymbol{r}^{\mathbf{2}}$ \\
\hline RB173 & $1.29 \pm 0.52$ & $24.41 \pm 0.25$ & $31.22 \pm 0.16$ & $3.10 \pm 0.06$ & 0.95 \\
RB217 & $-0.91 \pm 0.55$ & $25.31 \pm 0.24$ & $30.62 \pm 0.08$ & $3.79 \pm 0.06$ & 0.91 \\
RB221 & $-4.15 \pm 0.64$ & $25.24 \pm 0.22$ & $30.90 \pm 0.10$ & $3.55 \pm 0.04$ & 0.93 \\
RB226 & $0.69 \pm 0.50$ & $24.63 \pm 0.23$ & $30.86 \pm 0.10$ & $3.31 \pm 0.06$ & 0.93 \\
RB228 & $0.74 \pm 0.64$ & $23.86 \pm 0.40$ & $31.78 \pm 0.38$ & $3.79 \pm 0.12$ & 2.65 \\
RB235 & $-1.92 \pm 0.63$ & $23.68 \pm 0.22$ & $30.96 \pm 0.10$ & $3.32 \pm 0.05$ & 0.90 \\
\hline
\end{tabular}

a $r^{2}$, determination coefficient; RMSE, root mean square error; $T_{\max }$, maximum growth temperature; $T_{\min }$, minimum growth temperature; $T_{\text {opt }}$, optimum growth temperature; $\mu_{\text {opt }}$, radial growth rate at optimum temperature. 
(CBS 129944) was isolated from Ceylon cinnamon tree (Cinnamomum zeylanicum) and identified as C. lupini species (Damm et al. 2012). The two ITS accession numbers of strain RB042, MH865693 and JQ948178, were submitted on the NCBI by Damm et al. (2012) and $\mathrm{Vu}$ et al. (2019). Based on the alignment of the RB042 sequence obtained in this study, we noticed that one nucleotide differed from the closest accession number MH865693 (Vu et al. 2019). The two TUB2 accession numbers of strain RB121, KJ018647 and AJ748629, were submitted on the NCBI by Baroncelli et al. (2015a) and Talhinhas et al. (2002). Based on the alignment of the RB121 sequence obtained in this study, we noticed that three nucleotides differed from the closest accession.

Morphological, physiological, and molecular studies enabled Nirenberg et al. (2002) to describe $C$. lupini as a separate species within the CAsc and characterized this species in two populations: C. lupini var. lupini and $C$. lupini var. setosum. A study in 2012 identified a higher degree of differences between strains based on the sequencing of six genes (Damm et al. 2012). In this study, two groups were observed based on eight sequence loci of 87 C. lupini strains and are qualified as group I and group II. These two groups belong to the A1 group described by Talhinhas et al. (2002) accepted as C. lupini (Damm et al. 2012). The smallest (group I) contains three strains, including the neotype strain RB173 (CBS 109225, UBOCC-A117263), RB235, and RB121 (IMI 504884, HY09), two of which were identified as C. lupini var. lupini by Nirenberg et al. (2002). All the other strains belonged to the largest group (group II), including RB172 identified as C. lupini var. setosum by Nirenberg et al. (2002) and RB020 (PT30) belonging to the most numerous subgroup of A1 described by Talhinhas et al. (2002). In our study, the two groups were not distributed by geographical origin or specific morphological characteristics. The three strains of group I were isolated from Ukraine, France, and Canada. All isolates from our collections were included in the second group. Furthermore, the eight loci used were sufficient to discriminate the strains within each group. Additional markers, including single-nucleotide polymorphism markers or microsatellites, must be devised to better characterize genetic diversity at the intraspecific level and determine to which extent isolates within each group may originate from a clonal population.

All studied strains shared common morphological characteristics of $C$. lupini, such as the color of the mycelium. However, we noticed that none of our strains produced pink colonies with abundant orange spore masses, unlike some strains described by Talhinhas et al. (2002). Another morphological characteristic, also described for Australian lupin isolates (Yang and Sweetingham 1998), was the presence of a pale regular margin, which was present only for strains RB121, RB173, RB235, and PN179.
Microsclerotia were observed for RB121, RB228, RB217, and PN179 by the development of black mass structures on mycelium only under cocultures with itself or other isolates. RB121 was previously described in the literature (Nirenberg et al. 2002; Talhinhas et al. 2002), but these structures were never mentioned in its description. To our knowledge, microsclerotia have never been described within species belonging to the CAsc but are exclusively within the Colletotrichum truncatum s.l. species (Buchwaldt et al. 1996; Freeman et al. 2012). Microsclerotia allow the fungus to lie dormant in the soil during winter or under stressed conditions. Because microsclerotia were exclusively observed under cocultures, confrontation may induce the development of such conservation structures.

C. lupini has been identified as the only pathogenic agent for spring and winter lupin crops. Apparition of symptoms on winter lupins at spring raises the need to understand how $C$. lupini colonizes the plant during winter.

Radial growth modeling showed that $T_{\min }$ amplitude between strains was 5.45 versus $1.89^{\circ} \mathrm{C}$ for $T_{\text {opt }}$ and $0.92^{\circ} \mathrm{C}$ for $T_{\text {max }}$, suggesting that most variability was observed at low temperatures. $C$. lupini was not able to grow at $5^{\circ} \mathrm{C}$ for RB173 and RB217 and at $37^{\circ} \mathrm{C}$ for all strains. The same observation was made by other studies, which demonstrated that $C$. lupini was able to grow at temperatures ranging from 5 to $35^{\circ} \mathrm{C}$ (Baroncelli et al. 2015a; Thomas and Sweetingham 2004). Some strains, particularly those isolated during this study, were able to grow slowly at $5^{\circ} \mathrm{C}$. Estimated values of $T_{\text {min }}$ suggested the potential for these strains to grow under $2^{\circ} \mathrm{C}$, but this needs validation. Interestingly, after 40 days at $37^{\circ} \mathrm{C}$, mycelium was no longer able to grow when placed 4 more weeks at $25^{\circ} \mathrm{C}$, irrespective of strain (data not shown). This result indicates that a moderate thermal treatment may be used as a seed sanitization treatment. On L. angustifolius, seed infection was undetectable on 1,000 seeds after exposure for 1 to 4 days at $70^{\circ} \mathrm{C}$ or 8 days at $65^{\circ} \mathrm{C}$ (Thomas and Adcock 2004). Exposure of L. albus seeds for $<2$ weeks at $<70^{\circ} \mathrm{C}$ reduced germination $<15 \%$, which increased significantly with higher temperatures (Thomas and Adcock 2004).

Although no symptoms were observed $7 \mathrm{dpi}$ at 5 and $10^{\circ} \mathrm{C}$, even with detectable amounts of fungal DNA in the plant at $10^{\circ} \mathrm{C}$, symptoms appeared the day after the plant was placed at $25^{\circ} \mathrm{C}$ (data not shown). DNA quantification at $5^{\circ} \mathrm{C}$ at $21 \mathrm{dpi}$ for RB221 and RB226 suggests that $C$. lupini is able to grow in planta at low temperature (Fig. 4). Optimal growth temperatures were significantly lower for RB226 $\left(T_{\text {opt }}=24.63 \pm 0.23\right)$ than for RB221 $\left(T_{o p t}=25.24 \pm 0.22\right)$ based on our in vitro model. In planta,

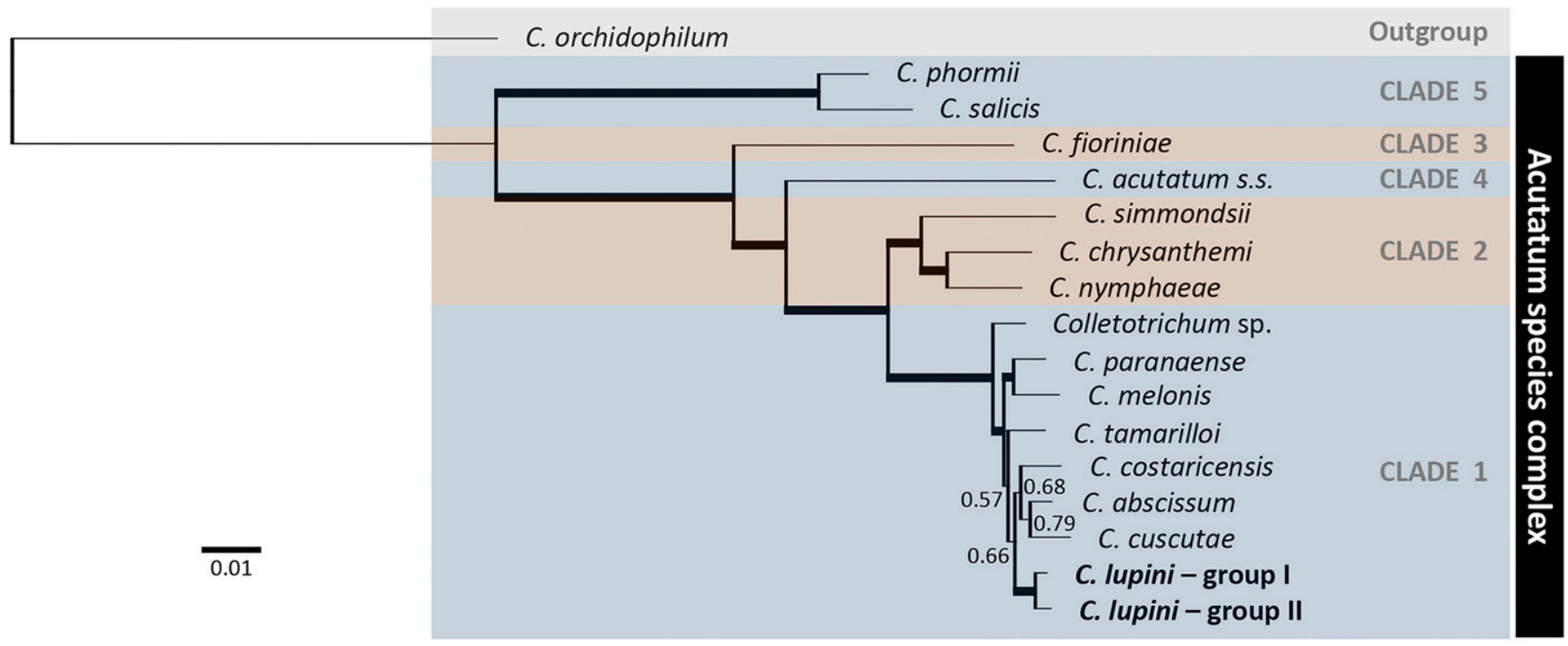

Fig. 1. Phylogenetic tree of Colletotrichum lupini isolates. Group I contains three C. lupini strains (RB121, RB235, and RB173), and group II contains all the other C. lupini strains studied. 
we also found that RB226 grew faster than RB221 under suboptimal conditions at $10^{\circ} \mathrm{C}$ with higher levels of necrosis and DNA. At 5 and $25^{\circ} \mathrm{C}$, growth was too slow or too fast, respectively, to differentiate the strains. Interestingly, whatever the strain, necrosis symptoms appeared on plants between 7 and 14 dpi at $10^{\circ} \mathrm{C}$, whereas fungal DNA was quantifiable earlier at $7 \mathrm{dpi}$, indicating that early detection of the pathogen in plants was possible before symptoms appeared. The molecular detection of C. lupini was also possible in spring and winter lupin fields, even in the absence of symptoms on the plants (Table 5). The design of primers specific to $C$. lupini developed in this study is the first step to develop an efficient molecular detection tool, which will enable producers to perform early detection of $C$. lupini in the field.

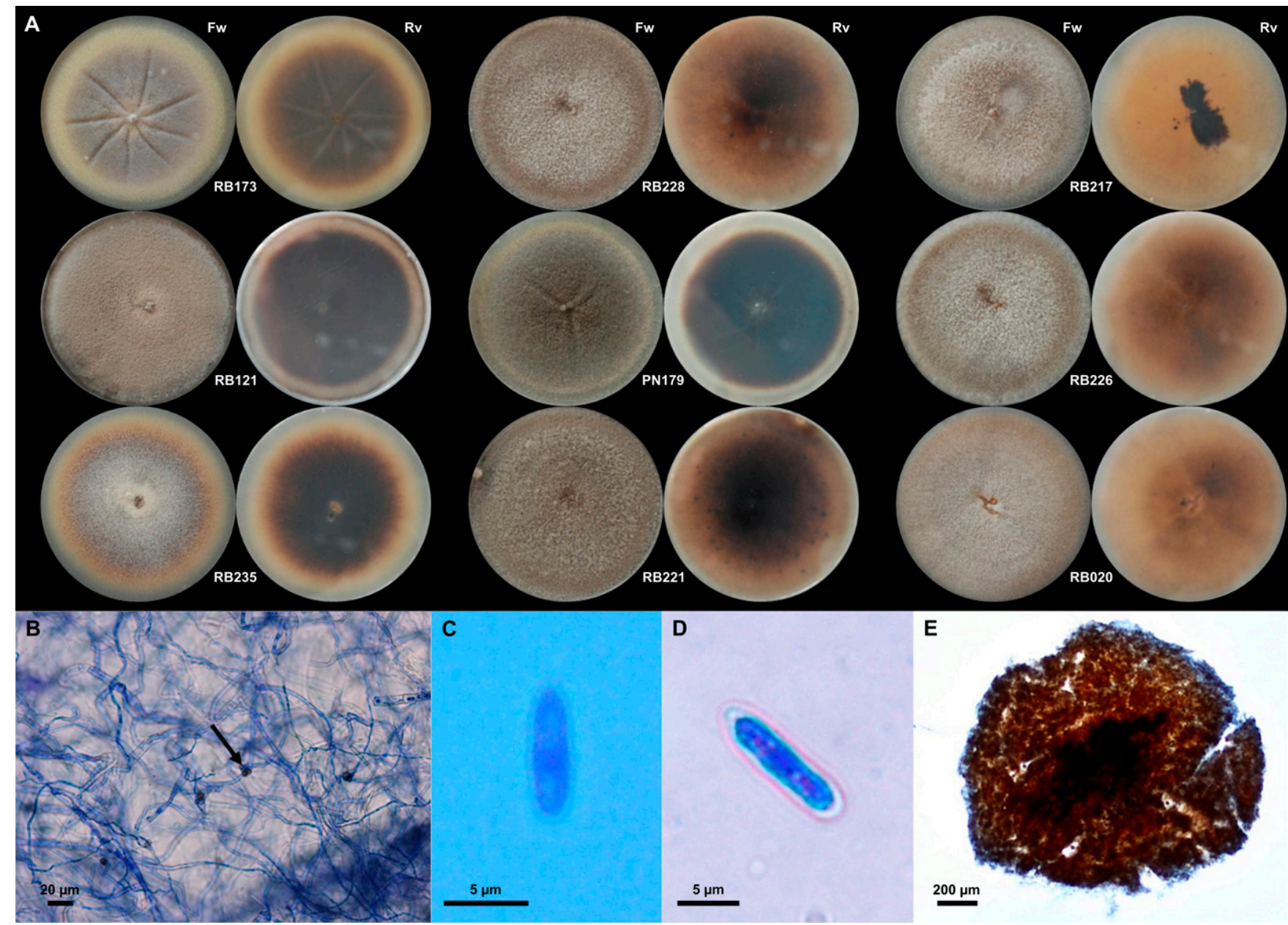

Fig. 2. Colletotrichum lupini strains for morphological diversity. A, Morphology of the mycelium of the nine strains on potato dextrose agar media plates viewed on forward (Fw) and reverse (Rv) sides. B, Appressoria of RB221. Conidia of C, RB226 and D, RB221. E, Microsclerotia of RB121.

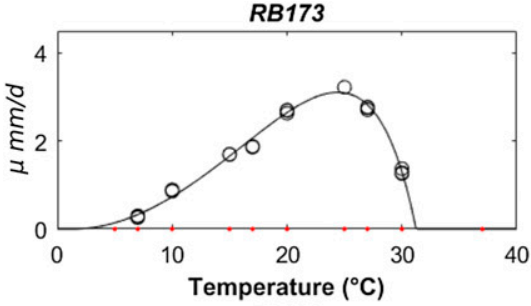

RB226

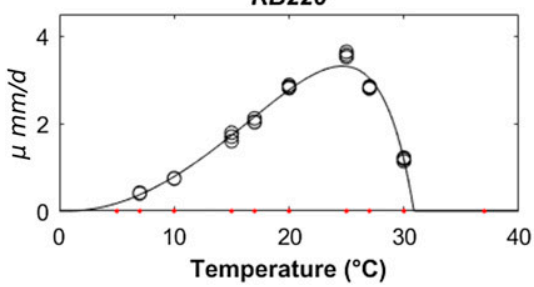

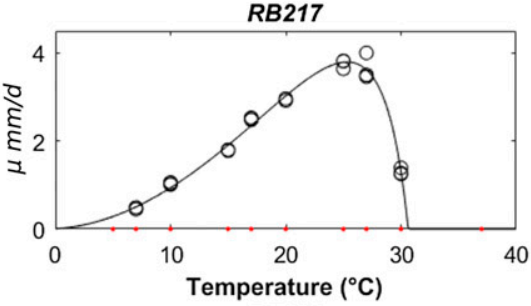

RB228

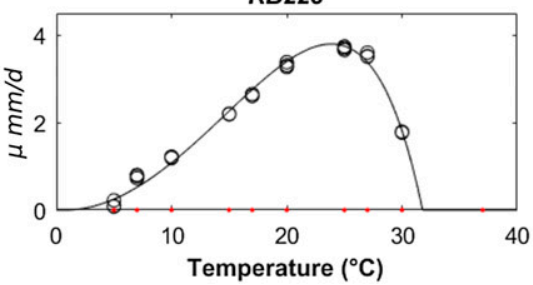

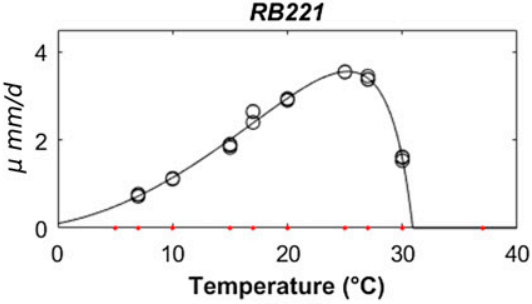

RB235

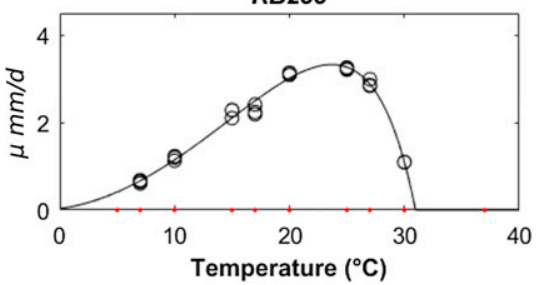

Fig. 3. Secondary models obtained for the six studied strains for temperature on potato dextrose agar medium. Radial growth (millimeters per day) of RB173, RB217, RB221, RB226, RB228, and RB235. Experimental data are indicated by $\bigcirc$, and calculated values according to equation 2 are indicated by - . 


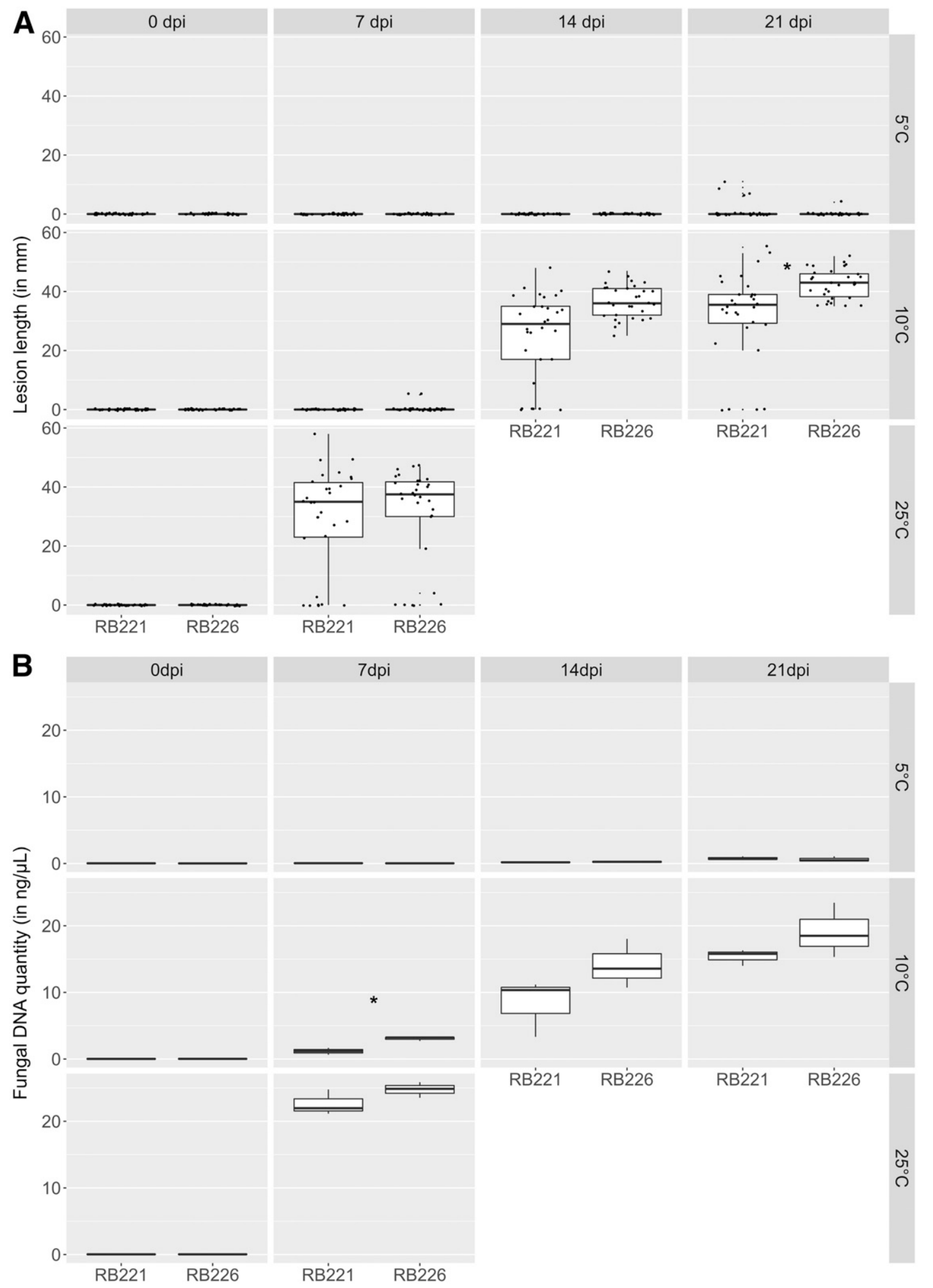

Fig. 4. Box plots of A, lesion length and B, fungal DNA quantification inoculated with either RB221 or RB226 on two leaf-stage plants and incubated between 7 and 21 days postinoculation (dpi) at low temperature $\left(5\right.$ and $\left.10^{\circ} \mathrm{C}\right)$. ${ }^{*}$ Significant differences between strains at each condition (analysis of variance, Tukey post hoc, $\left.P<0.05\right)$.

Table 5. Quantification of Colletotrichum lupini DNA from lupin samples collected from winter and spring lupin fields over the plant growth

\begin{tabular}{cccccc}
\hline & $\begin{array}{c}\text { Number of } \\
\text { fields }\end{array}$ & $\begin{array}{c}\text { Number of fields } \\
\text { with } \\
\text { visual symptoms }\end{array}$ & $\begin{array}{c}\text { Number of total } \\
\text { samples }\end{array}$ & $\begin{array}{c}\text { Number of samples with DNA levels } \\
\text { above LOQ/number of fields }\end{array}$ & $\begin{array}{c}\text { Number of samples with DNA above } \\
\text { LOQ and without symptoms }\end{array}$ \\
\hline $\begin{array}{c}\text { Winter } \\
\text { lupin }\end{array}$ & 10 & 2 & 39 & $5(0.004 \mathrm{ng}$ DNA $) / 4$ fields & $3(0.001 \mathrm{ng}$ DNA $)$ \\
$\begin{array}{c}\text { Spring } \\
\text { lupin }\end{array}$ & 2 & 0 & 8 & $1(0.001 \mathrm{ng}$ DNA $) / 1$ field & 1 \\
\hline a & & & &
\end{tabular}




\section{Acknowledgments}

Strains were obtained from the Université de Bretagne Occidentale Culture Collection (Plouzané, France; https://www.univ-brest.fr/ubocc). We thank Morgane Chalopin for her contribution to the molecular biology experiments and Sylvie Tréguer for preparing media. Some experimental contributions were made by internship students: Henri Lepilleur, Daniele Da Lio, and Pierre Baldo.

\section{Literature Cited}

Baroncelli, R., Sarrocco, S., Zapparata, A., Tavarini, S., Angelini, L. G., and Vannacci, G. 2015a. Characterization and epidemiology of Colletotrichum acutatum sensu lato (C. chrysanthemi) causing Carthamus tinctorius anthracnose. Plant Pathol. 64:375-384.

Baroncelli, R., Zapparata, A., Sarrocco, S., Sukno, S. A., Lane, C. R., Thon, M. R., Vannacci, G., Holub, E., and Sreenivasaprasad, S. 2015b. Molecular diversity of anthracnose pathogen populations associated with UK strawberry production suggests multiple introductions of three different Colletotrichum species. PLoS One 10:e0129140.

Bondar, G. 1912. Tremoco branco e suas molestias. Bol. Agric. São Paulo 13: 427-432.

Bragança, C. A. D., Damm, U., Baroncelli, R, Massola Junior, N. S., and Crous, P. W. 2016. Species in the Colletotrichum acutatum complex associated with anthracnose diseases of fruit in Brazil. Fungal Biol. 120:547-561. doi: 10.1016/j.funbio.2016.01.011

Buchwaldt, L., Morrall, R. A. A., Chongo, G., and Bernier, C. C. 1996. Windborne dispersal of Colletotrichum truncatum and survival in infested lentil debris. Phytopathology 86:1193-1198.

Cannon, P. F., Buddie, A. G., and Bridge, P. D. 2008. The typification of Colletotrichum gloeosporioides. Mycotaxon 104:189-204.

Carbone, I., and Kohn, L. M. 1999. A method for designing primer sets for speciation studies in filamentous ascomycetes. Mycologia 91:553-556.

Cowling, W. A., Buirchell, B. J., and Tapia, M. E. 1998. Promoting the conservation and use of underutilized and neglected crops. Pages 8-33 in: Lupin, Lupinus L. J. Heller, J. Engels, and K. Hammer, eds. Institute of Plant Genetics and Crop Plant Research, Gatersleben, and International Plant Genetic Resources Institute, Rome, Italy.

Crous, P. W., Groenewald, J. Z., Risède, J.-M., Simoneau, P., and Hyde, K. D. 2006. Calonectria species and their Cylindrocladium anamorphs: Species with clavate vesicles. Stud. Mycol. 55:213-226.

Dagnas, S., and Membré, J.-M. 2013. Predicting and preventing mold spoilage of food products. J. Food Prot. 76:538-551.

Damm, U., Cannon, P. F., Woudenberg, J. H. C., and Crous, P. W. 2012. The Colletotrichum acutatum species complex. Stud. Mycol. 73:37-113.

Dean, R., Van Kan, J. A. L., Pretorius, Z. A., Hammond-Kosack, K. E., Di Pietro, A., Spanu, P. D., Rudd, J. J., Dickman, M., Kahmann, R., Ellis, J., and Foster, G. D. 2012. The Top 10 fungal pathogens in molecular plant pathology. Mol. Plant Pathol. 13:414-430.

Decker, P. 1947. Anthracnose of blue lupine is seed-borne. Plant Dis. Rep. 31: 270-271.

Diggle, A. J., Salam, M. U., Thomas, G. J., Yang, H. A., O'Connell, M., and Sweetingham, M. W. 2002. AnthracnoseTracer: A spatiotemporal model for simulating the spread of anthracnose in a lupin field. Phytopathology 92:1110-1121.

Freeman, A., Spackman, M., and Lindbeck, K. 2012. A surveillance survey for lentil anthracnose in Victorian lentil crops using high throughput PCR testing. Australas. Plant Dis. Notes 7:177-180.

Gondran, J., Deneufbourg, F., and Vuillaume, E. 1990. Colletotrichum gloeosporioides of white lupin (biology, seed dressing with chemicals, breeding for resistance). Pages 322-325 in: Proceedings of the 6th International Lupin Conference. D. Von Baer, ed. International Lupin Association, Temuco-Pucon, Chile.

Gondran, J., and Pacault, D. 1997. White lupin anthracnose [Colletotrichum acutatum Simmonds]. Phytoma 494:28-31.

Guerber, J. C., Liu, B., Correll, J. C., and Johnston, P. R. 2003. Characterization of diversity in Colletotrichum acutatum sensu lato by sequence analysis of two gene introns, mtDNA and intron RFLPs, and mating compatibility. Mycologia 95:872-895.

Jayawardena, R., Hyde, K. D., Damm, U., Cai, L., Liu, M., Li, X., Zhang, W., Zhao, W., and Yan, J. 2016. Notes on currently accepted species of Colletotrichum. Mycosphere. 7:1192-1260.

Katoh, K., and Standley, D. M. 2013. MAFFT multiple sequence alignment software version 7: Improvements in performance and usability. Mol. Biol. Evol. 30:772-780.

Kearse, M., Moir, R., Wilson, A., Stones-Havas, S., Cheung, M., Sturrock, S., Buxton, S., Cooper, A., Markowitz, S., Duran, C., Thierer, T., Ashton, B., Meintjes, P., and Drummond, A. 2012. Geneious Basic: An integrated and extendable desktop software platform for the organization and analysis of sequence data. Bioinformatics 28:1647-1649.

Kumar, S., Stecher, G., and Tamura, K. 2016. MEGA7: Molecular evolutionary genetics analysis version 7.0 for bigger datasets. Mol. Biol. Evol. 33:1870-1874.

Lee, M. R. F., Parkinson, S., Fleming, H. R., Theobald, V. J., Leemans, D. K., and Burgess, T. 2016. The potential of blue lupins as a protein source, in the diets of laying hens. Vet. Anim. Sci. 1-2:29-35.

Lotter, H. C., and Berger, D. K. 2005. Anthracnose of lupins in South Africa is caused by Colletotrichum lupini var. setosum. Australas. Plant Pathol. 34:385-392.
Morin-Sardin, S., Rigalma, K., Coroller, L., Jany, J.-L., and Coton, E. 2016. Effect of temperature, $\mathrm{pH}$, and water activity on Mucor spp. growth on synthetic medium, cheese analog and cheese. Food Microbiol. 56:69-79.

Nguyen Van Long, N., Vasseur, V., Coroller, L., Dantigny, P., Le Panse, S. Weill, A., Mounier, J., and Rigalma, K. 2017. Temperature, water activity and $\mathrm{pH}$ during conidia production affect the physiological state and germination time of Penicillium species. Int. J. Food Microbiol. 241:151-160.

Nirenberg, H. I., Feiler, U., and Hagedorn, G. 2002. Description of Colletotrichum lupini comb. nov. in modern terms. Mycologia 94:307-320.

Ratkowsky, D. A. 2004. Model fitting and uncertainty. Pages 151-196 in: Modeling Microbial Responses in Food. R. C. McKellar and X. Lu, eds. CRC Press, Boca Raton, FL.

Ronquist, F., and Huelsenbeck, J. P. 2003. MrBayes 3: Bayesian phylogenetic inference under mixed models. Bioinformatics 19:1572-1574.

Rosso, L. 1995. Modélisation et microbiologie prévisionnelle: Elaboration d'un nouvel outil pour l'agro-alimentaire. Thesis, Université Claude Bernard place, Lyon, France.

Saubeau, G., Gaillard, F., Legentil, L., Nugier-Chauvin, C., Ferrières, V., Andrivon, D., and Val, F. 2014. Identification of three elicitins and a galactan-based complex polysaccharide from a concentrated culture filtrate of Phytophthora infestans efficient against Pectobacterium atrosepticum. Molecules 19:15374-15390.

Seymour, A. B. 1929. Host Index of Fungi of North America. Harvard University Press, Cambridge, MA.

Sreenivasaprasad, S., and Talhinhas, P. 2005. Genotypic and phenotypic diversity in Colletotrichum acutatum, a cosmopolitan pathogen causing anthracnose on a wide range of hosts. Mol. Plant Pathol. 6:361-378.

Sweetingham, M. W., Thomas, G., Yang, H., and Shea, G. 1998a. Anthracnose-the pathogen, epidemiology and the management package. Pages 8-9 in: Highlights of Lupin Research and Development in Western Australia. G. Shea, ed. The Chief Executive Officer, Agriculture Western Australia, Perth, Australia.

Sweetingham, M. W., Jones, R. A. C., and Brown, A. G. P. 1998b. Diseases and pests. Pages 263-289 in: Lupins as Crop Plants: Biology, Production and Utilization. J. S. Gladstones, C. Atkins, and J. Hamblin, eds. CAB International, Wallingford, United Kingdom.

Talhinhas, P., Baroncelli, R., and Le Floch, G. 2016. Anthracnose of lupins caused by Colletotrichum lupini: A recent disease and a successful worldwide pathogen. J. Plant Pathol. 98:5-14.

Talhinhas, P., Sreenivasaprasad, S., Neves-Martins, J., and Oliveira, H. 2002. Genetic and morphological characterization of colletotrichum acutatum causing anthracnose of lupins. Phytopathology 92:986-996.

TeBeest, D. O. 1988. Additions to host range of Colletotrichum gloeosporioides $\mathrm{f}$. sp. aeschynomene. Plant Dis. 72:16-18.

Thomas, G. J., and Adcock, K. G. 2004. Exposure to dry heat reduces anthracnose infection of lupin seed. Australas. Plant Pathol. 33:537-540.

Thomas, G. J., and Sweetingham, M. W. 2004. Cultivar and environment influence the development of lupin anthracnose caused by Colletotrichum lupini. Australas. Plant Pathol. 33:571-577.

Thomas, G. J., Sweetingham, M. W., Yang, H. A., and Speijers, J. 2008. Effect of temperature on growth of Colletotrichum lupini and on anthracnose infection and resistance in lupins. Australas. Plant Pathol. 37:35-39.

Vu, D., Groenewald, M., de Vries, M., Gehrmann, T., Stielow, B., Eberhardt, U., Al-Hatmi, A., Groenewald, J. Z., Cardinali, G., Houbraken, J., Boekhout, T., Crous, P. W., Robert, V., and Verkley, G. J. M. 2019. Large-scale generation and analysis of filamentous fungal DNA barcodes boosts coverage for kingdom fungi and reveals thresholds for fungal species and higher taxon delimitation. Stud. Mycol. 92:135-154. doi:10.1016/j.simyco.2018.05.001

Weidemann, G. J., TeBeest, D. O., and Cartwright, R. D. 1988. Host specificity of Colletotrichum gloeosporioides $\mathrm{f}$. sp. aeschynoemene and C. truncatum in the Leguminosae. Phytopathology 78:986-990.

Weimer, J. L. 1943. Anthracnose of lupines. Phytopathology 33:249-252.

Weimer, J. L. 1951. Anthracnose resistance in lupines. Plant Dis. Rep. 33:80-82.

Weimer, J. L. 1952. Lupine anthracnose. Circular of the US Department of Agriculture. USDA, Washington, DC.

Wells, H. D., and Bell, D. K. 1969. Fungal pathogenicity to sound and mechanically damaged blue lupine seed in axenic culture at two temperatures. Plant Dis. Rep. 53:774-776.

Wells, H. D., and Forbes, I. 1967. Effects of temperature on growth of Glomerella cingulata in vitro and on its pathogenicity to Lupinus angustifolius genotypes an and An. Phytopathology 57:1309-1311.

White, P., French, B., McLarty, A., and Grains Research and Development Corporation. 2008. Producing lupins. Bulletin 4720. Department of Agriculture and Food, Perth, Western Australia.

White, T. J., Bruns, T., Lee, S. J. W. T., and Taylor, J. L. 1990. Amplification and direct sequencing of fungal ribosomal RNA genes for phylogenetics. Pages 315-322 in: PCR Protocols, a Guide to Methods and Applications. M. Innis, D. Gelfand, J. Shinsky, and T. White, eds. Academic Press, San Diego, CA.

Woudenberg, J. H. C., Aveskamp, M. M., de Gruyter, J., Spiers, A. G., and Crous, P. W. 2009. Multiple Didymella teleomorphs are linked to the Phoma clematidina morphotype. Persoonia 22:56-62.

Yang, H. A., and Sweetingham, M. W. 1998. The taxonomy of Colletotrichum isolates associated with lupin anthracnose. Aust. J. Agric. Res. 49:1213-1224. 